\title{
Farming practices affect the amino acid profiles of the aquaculture Chinese mitten crab
}

\author{
Qingfei Zeng ${ }^{\text {Corresp., } 1}$, Yuxia Xu ${ }^{2}$, Erik Jeppesen ${ }^{3,4,5}$, Xiaohong Gu $^{1}$, Zhigang Mao $^{1}{ }^{1}$, Huihui Chen ${ }^{1}$ \\ ${ }^{1}$ State Key Laboratory of Lake Science and Environment, Nanjing Institute of Geography and Limnology, Chinese Academy of Sciences, Nanjing, China \\ ${ }^{2}$ Key Lab of Disaster Monitoring and Mechanism Simulating of Shaanxi Province, Baoji University of Arts and Sciences, Baoji, China \\ 3 Sino-Danish Centre for Education and Research, University of Chinese Academy of Sciences, Beijing, China \\ 4 Limnology Laboratory, Department of Biological Sciences and Centre for Ecosystem Research and Implementation, Middle East Technical University, \\ Ankara, Turkey \\ 5 Department of Bioscience, Aarhus University, Silkeborg, Denmark \\ Corresponding Author: Qingfei Zeng \\ Email address: qfzeng@niglas.ac.cn
}

Farming operation and amino acid profiles of pond-reared Chinese mitten crabs, Eriocheir sinensis (Milne Edwards, 1853), collected from different areas in Jiangsu Province, China were investigated and compared with the aim to elucidate how farming practices affected the nutritional values of three edible tissues (muscle, hepatopancreas and gonad) of crab . The crab pond aquaculture practices including snail input, macrophytes coverage, total commercial feed, the ratio of trash fish to total feed, were much higher in Gaochun and Jintan than that in other sites (having larger pond size), which leads to higher average individual body weight and commercial yields. Further, the mean body weight, muscle weight, carapace length and width, and the ratio of gonad to hepatopancreas were significantly higher in Jintan, Suzhou and Gaochun areas than in other regions. Amino acid assessment showed that all crabs collected delivered high-quality protein (Amino acid score $>1$ except Valine), the main amino acids being Glutamic acid, Aspartic acid, and Alanine. Significant differences in amino acid profiles were observed between sites, tissues and sexes. Muscles were rich in total amino acids, essential amino acids, and delicious amino acids, followed by gonads and hepatopancreas. The contents of essential amino acids in crab muscles from Gaochun, Jintan, Suzhou and Guannan were significantly higher than those from Suqian, Sihong and Xinghua. All the amino acids except Serine and Glycine were significantly higher in gonads from males than from females. The redundancy analysis revealed that the snail input, trash fish ratio to the total feed, macrophytes coverage and total trash fish supply explained $84.3 \%$ of the variation in the amino acid content and structure in crabs from Gaochun, Jintan and Suzhou. Overall, our results show that mitten crabs collected in Jiangsu province had good nutritional quality suitable for human dietary needs, and that farming practices, especially degree of fish-source protein 
feeding, influence the amino acids composition of crabs. 
1 Farming practices affect the amino acid profiles of the 2 aquaculture Chinese mitten crab

4 Qingfei Zeng a , Yuxia Xu ${ }^{\text {b }}$, E. Jeppesen ${ }^{\mathrm{c}, \mathrm{d}, \mathrm{e}}$, Xiaohong Gu ${ }^{\mathrm{a}}$, Zhigang Mao ${ }^{\mathrm{a}}$, Huihui Chen a

5 a State Key Laboratory of Lake Science and Environment, Nanjing Institute of Geography and

6 Limnology, Chinese Academy of Sciences, Nanjing, China

7 bKey Lab of Disaster Monitoring and Mechanism Simulating of Shaanxi Province, Baoji

8 University of Arts and Sciences, Baoji, China

$9 \quad$ 'Department of Bioscience, Aarhus University, Silkeborg, Denmark

10 dSino-Danish Centre for Education and Research, University of Chinese Academy of Sciences,

11 Beijing, China

12 éLimnology Laboratory, Department of Biological Sciences and Centre for Ecosystem Research

13 and Implementation, Middle East Technical University, Turkey

15 Corresponding Author:

16 Qingfei Zeng

1773 Beijing East Road, Nanjing, Jiangsu Province, China

18 Email address: qfzeng@niglas.ac.cn 


\section{Abstract}

Farming operation and amino acid profiles of pond-reared Chinese mitten crabs, Eriocheir sinensis (Milne Edwards, 1853), collected from different areas in Jiangsu Province, China were investigated and compared with the aim to elucidate how farming practices affected the nutritional values of three edible tissues (muscle, hepatopancreas and gonad) of crab. The crab pond aquaculture practices including snail input, macrophytes coverage, total commercial feed, the ratio of trash fish to total feed, were much higher in Gaochun and Jintan than that in other sites (having larger pond size), which leads to higher average individual body weight and commercial yields. Further, the mean body weight, muscle weight, carapace length and width, and the ratio of gonad to hepatopancreas were significantly higher in Jintan, Suzhou and Gaochun areas than in other regions. Amino acid assessment showed that all crabs collected delivered high-quality protein (Amino acid score $>1$ except Valine), the main amino acids being Glutamic acid, Aspartic acid, and Alanine. Significant differences in amino acid profiles were observed between sites, tissues and sexes. Muscles were rich in total amino acids, essential amino acids, and delicious amino acids, followed by gonads and hepatopancreas. The contents of essential amino acids in crab muscles from Gaochun, Jintan, Suzhou and Guannan were significantly higher than those from Suqian, Sihong and Xinghua. All the amino acids except Serine and Glycine were significantly higher in gonads from males than from females. The redundancy analysis revealed that the snail input, trash fish ratio to the total feed, macrophytes coverage and total trash fish supply explained $84.3 \%$ of the variation in the amino acid content and structure in crabs from Gaochun, Jintan and Suzhou. Overall, our results show that mitten crabs collected in Jiangsu province had good 
41 nutritional quality suitable for human dietary needs, and that farming practices, especially degree of fish-source protein feeding, influence the amino acids composition of crabs.

Keywords: Chinese mitten crabs; Amino acid; Farming practices; NMDS

\section{Introduction}


62 variation in stocking density, macrophytes transplanting, snail input, differed significantly

63 between farming areas, especially between the south area and north area in the province (Wang et

64 al., 2016a). Several studies have reported that environmental and dietary differences affect the

65 protein content and amino acid profiles (Kasozi et al., 2019; Hussain et al., 2018; Liu et al., 2018).

66 Wild-caught crabs, such as swimming crab, mud crab, and Chinese mitten crab, exhibit better

67 nutritional value than cultured crabs (Liu et al., 2018). However, there have been few studies

68 focused on the nutrition quality of cultured crabs subjected to different farming practices.

69 Amino acids are essential nutrients for human growth, physiology, biochemistry and immunity

70 (Liu et al., 2018; Liu et al., 2019). Some amino acids give certain flavors in the crab, such as

71 aspartic acid (umami), threonine (sweet), and arginine (bitter/sweet) (Kong et al., 2012). These

72 amino acids can increase attractiveness of the products for the customers. Therefore, study on the

73 composition of amino acids of mitten crab tissues is of key importance in assessing the nutritional

74 and flavor quality of the crab. However, there are no detailed information available about how the

75 farming pattern affects the nutritional quality of pond-reared crabs and why the flavor differs

76 between farming areas, that otherwise could help guiding consumers to choose their favorite food

77 and farmers to optimize farming practices.

78 We investigated the amino acids composition in three edible tissues of both sexes to elucidate

79 to what extent the nutritional value of mitten crabs is affected by farming patterns. We expected

80 significant differences in amino acids compositions of mitten crabs due to differences in feeding

81 praxis between southern and northern Jiangsu Province (Taking the Yangtze River as the boundary

82 between north and south area). 


\section{Methods and materials}

\section{Schematic overview of study}

Figure 1 shows the schematic overview of the study. Herein, both sample collection and farming practices survey was carried out at the same time when the crabs were harvested. Then the crabs were dissected to three edible tissues of both sexes for further growth performance and amino acid analysis. The drivers of amino acids composition of mitten crabs cultured in different farming patterns using a redundancy analysis (RDA).

\section{Sample preparation}

The mitten crabs were sampled in November 2018 from seven major aquaculture areas in Jiangsu Province, China (Fig.2). Ten intact crabs, 5 males and 5 females, were randomly selected in each pond ( 2 ponds at each sampling area) and transported on ice alive to the laboratory. The body weight and carapace dimensions (carapace length (CL) and carapace width (CW)) were measured for each individual. Crabs were dissected, and their muscles, hepatopancreas and gonads were weighted and freeze-dried for later further analysis. Since the hepatopancreas and gonads from a single crab had relatively low total weight, the tissue from 5 crabs of each sex per pond were pooled to form for amino analysis. All analyses were repeated twice at each culture area.

\section{Farming practices survey}

The farming practices survey was conducted from farmer during crab sampling (2-4 ponds at each sampling area), including the pond size, stock density, feed composition, macrophytes coverage, and yield. 
104

105

106

107

108

109

110

111

112

113

114

115

116

117

118

119

120

121

122

123

124

\section{Growth performance}

The hepatopancreas index (HSI), gonadosomatic index (GSI), the ratio of gonad to hepatopancreas ( $\mathrm{GH}$ ratio), and condition factor $(\mathrm{CF})$ of the crabs were calculated using the following formulas (1)-(4), respectively:

$$
\begin{aligned}
& H S I(\%)=\frac{\text { hepatopancreas wet weight }}{\text { body weight }} \times 100 \\
& G S I(\%)=\frac{\text { gonad wet weight }}{\text { body weight }} \times 100 \\
& G H=\frac{\text { gonad wet weight }}{\text { hepatopancreas wet weight }} \\
& C F=\frac{\text { body weight }}{\text { carapace length }^{3}}
\end{aligned}
$$

\section{Amino acid profiles}

3 The analysis was conducted using an automatic amino acid analyzer (L-8900, Hitachi) following 4 Chen, Zhang, \& Shrestha (2007). Duplicated samples were hydrolyzed with $6 \mathrm{~mol} \mathrm{~L}^{-1} \mathrm{HCl}$ for 24 $\mathrm{h}$ at $110^{\circ} \mathrm{C}$. Hydrolysates were then dissolved in distilled water to a total of $100 \mathrm{ml}$. A total of 1 $\mathrm{mL}$ of hydrolysate was freeze-dried under vacuum to remove water and $\mathrm{HCl}$. Then, $2 \mathrm{~mL}$ of 0.02 mol L-1 $\mathrm{HCl}$ was supplemented to solution. One $\mathrm{mL}$ of solution filtered through $0.22 \mu \mathrm{m}$ pore size membrane was used for amino acid analysis. The amino acid profiles were detected by comparing the retention time and peaks with those of amino acid standard (EZChrom Elite for Hitachi Version 3.1).

\section{Nutritional evaluation}

22 The nutritional evaluation was carried out according to the guidelines of the Food and

Agriculture Organization (FAO) for amino acid score and egg protein amino acid score (FAO/WHO, 1991). The formulas (5-7) for amino acid score (AAS), chemical score (CS), and 
125

126

127

128

129

130

131

132

133

134

135

136

137

138

139

140

141

142

143

144 145

essential amino acid index (EAAI) are as follows:

$$
\begin{aligned}
& A A S(\%)=\frac{\text { sample amino acid content }(\%, \text { dry })}{\text { amino acid content in FAO reference (\%,dry) }} \times 100 \\
& C S(\%)=\frac{\text { sample amino acid content }(\%, \text { dry })}{\text { amino acid content in egg protein }(\%, \text { dry })} \times 100 \\
& E A A I=\sqrt[n]{\frac{100 a}{a_{\mathrm{e}}} \times \frac{100 b}{b_{\mathrm{e}}} \times \ldots \times \frac{100 h}{h_{\mathrm{e}}}}
\end{aligned}
$$

where $n$ is the number of essential amino acids compared, a-h are the levels of essential amino acids in the experiment $(\%$, dry $)$, and $\mathrm{a}_{\mathrm{e}}-\mathrm{h}_{\mathrm{e}}$ are the levels of amino acids in the egg protein $(\%$, dry).

\section{Statistical analysis}

All data were shown as mean \pm standard error (SE). Homogeneity of variance of data was tested with Levene's test. Two-way analysis of variance (ANONA) was performed to analyze the differences in amino acid profile and growth performance for the effect of sex $(\uparrow, \overbrace{}^{\Uparrow})$ and location (7 sites) using software SPSS 18.0. Alpha level of $p<0.05$ was accepted as a measure of significant intergroup difference. When the overall treatment effect was significantly different, Duncan's multiple range test was conducted to compare the means of the individual treatments.

We investigated drivers of amino acids composition of mitten crabs cultured in different farming patterns using a RDA in software CANOCO 4.5. RDA is a direct gradient ordination analysis which summarizes the linear relationship between a multivariate set of response variables to explanatory variables. To investigate the spatial variation of amino acids among the sampling sites, non-metric multidimensional scaling (NMDS) was carried out using PAST 3.0 according to Bray-

3 Curtis similarities using standardized and square-root converted data. Analysis of similarities 44 (ANOSIM) was conducted to test statistically whether there is a significant difference in amino acid profiles among the locations. 


\section{Results}

\section{Farming practice}

149 The farming practices of Chinese mitten crab is shown in Fig.3. Coin-sized mitten crabs

150 (generally 5.5-7.0 g per individual) were usually chosen for culture at a density ranged from

$1511.5 \times 10^{4}$ to $2.9 \times 10^{4}$ individual ha-1 (Fig.3A). The pond size in Suqian, Sihong, Gaochun and Jintan

152 was around $1 \mathrm{ha}$, being much lower than that in Guannan (20 ha) and Xinghua area (8.53 ha)

153 (Fig.3B). The snail input (Bellamya aeruginosa, Reeve 1863) in the pond ranged from 0 to $12 \times 10^{3}$

$154 \mathrm{~kg} \mathrm{ha}^{-1}$ (Fig.3C) and macrophyte (mainly Elodea nuttallii (Planch.) H. St. John, 1920; Hydrilla

155 verticillata (Linn. f.) Royle, 1839; Vallisneria natans (Lour.) H. Hara, 1974) coverage from 45\%

156 to $70 \%$, being much higher in Gaochun and Jintan than that in other areas (Fig.3D). The

157 commercial pellet food, trash fish (mainly Hemiculter leucisculus Basilewsky, 1855), maize seed

158 and soybean were usually used as feed in mitten crab farming according to all farmers included in

159 the survey (Fig.3E). The total feed ranged from 9 to $13.8 \times 10^{3} \mathrm{~kg} \mathrm{ha}^{-1}$ and the ratio of trash fish to

160 total feed varied from 53\% to $78 \%$ in Gaochun, Jintan and Suzhou area, being much higher than

161 that in other areas (Fig.3F). The mitten crab yields varied between 1 and $2.7 \times 10^{3} \mathrm{~kg} \mathrm{ha}^{-1} \mathrm{cycle}^{-1}$

162 among the sites with an average individual body weight of $145 \mathrm{~g}$ in Gaochun and Jintan area

163 (Fig.3G\&H).

\section{Growth performance}

165 Almost all crab growth and tissue indices showed significant difference between sites and sex

166 (Table 1). The body weight $\left(F=316.14, p<0.0001, R^{2}=0.905\right)$, muscle weight $(F=126.62$, 
167

168

169

170

171

172

173

174

175

176

177

178

179

180

181

182

183

$\left.p<0.0001, R^{2}=0.875\right), \mathrm{CL}\left(F=42.21, p<0.0001, R^{2}=0.681\right), \mathrm{CW}\left(F=91.90, p<0.0001, R^{2}=0.769\right)$, and CF $\left(F=47.64, p<0.0001, R^{2}=0.549\right)$ of the male crabs was significantly higher, GSI\% $\left(F=783.29, p<0.0001, R^{2}=0.939\right)$ and $\mathrm{GH}$ ratio $\left(F=491.89, p<0.0001, R^{2}=0.913\right)$ were significantly lower than those of female crabs (Table 2). The mean body weight $\left(F=25.67, p<0.0001, R^{2}=0.905\right)$, muscle weight $\left(F=31.19, p<0.0001, R^{2}=0.875\right), \mathrm{CL}\left(F=10.46, p<0.0001, R^{2}=0.681\right), \mathrm{CW}$ $\left(F=11.87, p<0.0001, R^{2}=0.769\right)$, and $\mathrm{GH}$ ratio $\left(F=5.89, p<0.0001, R^{2}=0.913\right)$ were significantly higher in Jintan and Gaochun than in the other sites. HSI\% $\left(F=6.56, p<0.0001, R^{2}=0.488\right)$ was significantly higher in Xinghua and Guannan than in the other sites (Table 1, 2).

\section{Amino acid composition}

Seventeen amino acids were detected including seven essential amino acids in muscles, hepatopancreas and gonads of mitten crab. Muscles contained a higher total amnio acids (TAA), essential amnio acids (EAA), delicious amnio acids (DAA) and non-essential amino acids (NEAA), but had lower EAA/TAA ratio compared to gonads and hepatopancreas (Table 3). Generally, the content of Glutamic acid (Glu) was the highest (muscle 11.12 $\pm 0.14 \mathrm{mg} \mathrm{g}^{-1}$, hepatopancreas $1.32 \pm 0.05 \mathrm{mg} \mathrm{g}^{-1}$, gonads $7.28 \pm 0.14 \mathrm{mg} \mathrm{g}^{-1}$ ) followed by Aspartic acid (Asp) and Alanine (Ala) in all the three tissues. The content in the edible tissues of crabs varied significantly among locations and sex. In muscle, males had more Glu, Glycine (Gly) and Cystine (Cys) than females, and the contents of EAA in Gaochun, Jintan, Suzhou and Guannan were significantly higher than those in Suqian, Sihong and Xinghua (Table 4, 5, $F=7.49, p<0.001, R^{2}=0.844$ ). For hepatopancreas, male crabs usually had higher concentration of amino acids than females (Table S1). The concentrations of TAA $\left(F=11.67, p<0.0001, R^{2}=0.905\right)$, EAA $(F=10.44, p<0.0001$, 
$\left.R^{2}=0.895\right)$, DAA $\left(F=17.33, p<0.0001, R^{2}=0.934\right)$ and NEAA $\left(F=12.10, p<0.0001, R^{2}=0.909\right)$ in

Suzhou and Guannan were significantly higher than in the other locations (Table S1, 6). Largest differences were found in gonads and related to sex, as the contents of amino acids except Serine $(\operatorname{Ser})\left(F=1.91, p=0.188, R^{2}=0.213\right)$ and Gly $\left(F=1.27, p=0.279, R^{2}=0.698\right)$ were all significantly higher in males than in females (Table S2, 7).

\section{Nutritional evaluation}

All tissues had a high score for all essential amino acids (Table 8). The AAS and CS in hepatopancreas had the highest scores, followed in decreasing order by gonads and muscles. Hepatopancreas and muscles of mitten crabs in Gaochun showed an overall higher AAS and CS scores than that of other sites crabs. All the results were the similar for the EAAI of mitten crabs.

\section{Drivers of amino acids profile under different farming practices}

The ordination between farming practices and sampling sites is shown in Fig. 4A. The two principal components explained $84.3 \%$ of the variation. Amino acids contents in site Gaochun, Jintan and Suzhou were placed in the first and fourth quadrants, opposite to other sites, indicating a similar amino acid structure at these sites (Fig.4A). The RDA analysis revealed that the amino acid content and structure at site Gaochun, Jintan and Suzhou were best explained by snail input, trash fish ratio to the total feed, macrophytes coverage and total trash fish input. All the indices pointed in the same direction, while the stocking density and commercial feed showed a reversed position (Fig.4A). As illustrated in Fig.4B, Glu content was best explained by trash fish input, trash fish ratio to the total feed and the total fish. The EAA, such as Thr, Ile, Leu, Val and Phe, was best explained by the snail input. 
NMDS analysis showed separation between location and sex in the amino acids content of

muscle and gonad of crabs (Fig.5). All stress values were less than 0.1 , indicating a good fit by

Suqian were grouped together, and ANOSIM further verified distinct discrepancies with site

213 Gaochun, Jintan and Suzhou (Fig.5A, $p=0.0293$ ). In gonad, the amino acids content of crabs in

females was significantly different from that in males (Fig.5C, $p=0.0304$ ).

\section{Discussion}

The mitten crab farming practices differed largely among culture areas in Jiangsu Province,

especially between the south and north part (Refer to Fig. 5). Most differences in amino acid

composition were observed between culture areas, between types of tissues and for each tissue

also between sexes (Refer to Fig. 5). And the farming practices significantly and strongly affected the amino acids composition (Refer to Fig. 4).

Growth of crabs are depending on the available food resources and the quality of those.

Macrophytes play a key role in the mitten crab farming, providing natural food, reducing the nutrient loading from culture, and acting as efficient refuges against cannibalism (Zeng et al., 2019). Therefore, high macrophyte coverage is usually considered to enhance crab yield. Wang et

al. (2016a) found that the mitten crab yields in farms with a coverage $>30 \%$ were significantly

larger than with low coverage. Accordingly, we found the highest yield in Jintan $\left(2.7 \times 10^{3} \mathrm{~kg} \mathrm{ha}^{-1}\right.$

cycle $^{-1}$ ), having the highest macrophyte coverage (62.5\%) among the surveyed ponds, though we 
230 Fig. 3DG). Commercial pellet feed, trash fish, maize seed and soybean were commonly used as

231 feed in our study ponds (Refer to Fig. 3E). The crude protein content in commercial pellet feed

232 was $42.6 \%$, lower than in trash fish (64.2\%) (Refer to Table S3). The total feed and the ratio of 233 trash fish to total feed differed greatly among the sampling sites (Refer to Fig. 3CEF). And the 234 highest yield and average individual body weight were observed in Jintan with the highest total 235 feed and trash fish input (Refer to Fig. 3EFGH). Jin et al. (2013) found that the weight specific growth rate and protein efficiency ratio of juvenile swimming crab increased significantly when the dietary protein level increased from $31.6 \%$ to $50.2 \%$. Trash fish has been shown to improve the feed conversion rate and yield in these crab farming (Wang et al., 2016a, b), but excessive use of trash fish might cause environmental problems (Xu et al., 2020). Besides, replacing fish meal with plant-based or insect-based protein sources has become popular (Azarm \& Lee, 2014;

Sharawy, Goda, \& Hassaan, 2016), though this may affect amino acid metabolism and growth

performance as seen in a study by Yuan et al. (2019), with blunt snout bream (Megalobrama amblycephala Yih, 1955) where fish meals were replaced with cottonseed meal protein hydrolysate at high level (5 and 7\%) affecting the AMPK/SIRT1 pathway and inhibiting TOR signaling pathway.

246 We found the individual size, body weight and muscle weight of the male crabs was significantly higher than for females, while GSI\% and the GH ratio were significantly lower (Refer to Table 1\&2). Similar results have been found for other crustaceans (Barrento et al., 2010; Yu et al., 2019). The hepatopancreas is an important organ for the absorption and storage of nutrients, and can synthesize digestive enzymes for food digestion in crustaceans (Abol-Munafi et al, 2016), and 
251 higher HIS indicates improved hepatopancreatic development and immunity in crabs. GSI 252 measures the development and maturation of gonadal tissues relative to body weight (Wu et al., 253 2020). Data on HIS and GSI are usually impacted by diet protein and living environment. 254 Muhammad et al. (2019) found that the high water flow velocities inhibit the production of 255 hepatopancreas and gonad. Addition of glutathione can significantly increase HSI in Chinese 256 mitten crabs (Liu et al., 2019). But workers like Yu et al. (2019) and Butts et al. (2020) reported that diet with different protein did not influence organ-somatic indices (e.g. HSI, GSI). We found lower HIS of crabs in Gaochun and Jintan area, although higher-protein trash fish feed was input in these areas (Refer to Table 1).

Amino acids are the main constituent that have been used in assessing the nutritional value of the fishes (Azarm and Lee, 2014; Hussain et al., 2018) and crustaceans (Wang et al., 2018; Liu et al., 2019). Several studies have reported that differences in the amino acid content in the edible tissues of mitten crabs from different sampling sites may largely be attributed to environment and type of food they eat, but not elucidated how environment and food influenced the amino acid composition in detail (Wu et al., 2020; Liu et al., 2019). Generally, we found TAA, EAA and DAA in muscle and gonads to be significantly higher than in hepatopancreas (Refer to Table 3, 5, 6\&7). These results are consistent studies for other crustaceans (Barrento et al., 2009; Barrento et al., 2010; Wu et al., 2020). EAA are those that either cannot be synthesized or are inadequately synthesized by animals relative to needs (Akiyama et al., 1997). EAA need, therefore, be provided from the diet under conditions where rates of utilization are greater than rates of synthesis. EAA in muscle in Gaochun, Jintan, Suzhou and Guannan (characterized with higher trash fish input), 
272

274

275

276

277

278

279

280

281

282

283

284

285

286

287

288

289

290

291

292

were significantly higher than those in other study sites (Refer to Table 4\&5). DAA contribute to the flavor of the crab, which is an appealing flavor in mitten crab farming. Gly and Ala contribute to a sweet taste, whereas Glu and Asp provide a strong umami taste (Yamaguchi et al, 1971). In the present study, Glu was the main amino acid contributing to the umami taste in the mitten crabs. The DAA/TAA values were between 0.34 and 0.37 in all the tissues (Refer to Table 4, S1\&S2). It's similar to crustaceans reported in other studies, such as brown crab Cancer pagurus (Linné, 1758) (0.31-0.38) (Barrento et al., 2010), swimming crab Portunus trituberculatus (Miers, 1876) (0.30-0.37) (He et al., 2017) and Chinese mitten crab Eriocheir sinensis (Milne Edwards, 1853) (0.34-0.39) (Wang et al, 2018).

The EAA/TAA ratio, AAS, CS and EAAI are important factors when evaluating the nutritional quality of amino acid for fishery products (Guo et al., 2014; He et al. 2017; Wu et al., 2020). In our study, the average EAA/TAA values were 0.35 in muscles, 0.38 in hepatopancreas and 0.37 in gonads, which were close to the standard values (0.4) recommended by FAO/WHO (FAO/WHO, 1991) (Refer to Table 4, S1\&S2). No significant differences in EAA/TAA values were observed among sampling sites (Refer to Table $4 \& \mathrm{~S} 1$ ).

The AAS, CS, and EAAI values had the highest scores in the hepatopancreas followed by the muscle and gonads, thus hepatopancreas had the highest nutritional quality in terms of amino acids (Refer to Table 8). Hepatopancreas and muscles of mitten crabs in Gaochun showed overall higher AAS and CS scores than in crabs from the other sites (Refer to Table 8). Except for the Val, the AAS scores were higher than the FAO/WHO standard. The CS values of amino acids in the three parts were lower than the reference egg protein standard, except for Lys in muscles, Thr and Lys 
293 in hepatopancreas as well as Thr in gonads (Refer to Table 8). Similar results were observed in

$294 \mathrm{Wu}$ et al. (2020). The EAAI of some amino acid more than 100 indicates this amino acid is non-

295 limited and will meet the requirements of children or adults. The EAAI values ranged from 79.2

296 to 90.6 (average 84.6). Compared with other fishery products, the values were higher than in crabs

297 sampled from Yangchenghu Lake (66.5) (Guo et al., 2014), from rice-field (82.2) (Wu et al., 2020),

298 and in roach Paramisgurnus dabryanus (Dabry de Thiersant, 1872) (56.1) (Dong et al., 2018),

299 lower than in swimming crab Portunus trituberculatus (Miers, 1876) (146.8) (He et al., 2017), and

300 brown crab Cancer pagurus (Linné, 1758) (157.8) (Barrento et al., 2010). Therefore, all crab

301 sampled showed high nutritional value suitable for serving human dietary needs.

302 The amino acid content and structure in Gaochun, Jintan and Suzhou were best explained by

snail input, trash fish ratio to the total feed, macrophytes coverage and total trash fish supply (Refer

to Fig. 4). The environment, seasonal variations, sexual changes and the amount and quality of

food are key factors contributing to changes in amino acids content in marine species (Kasozi et

al., 2019). Liu et al. (2018) argued that a more balanced diet with fish, detritus and microalgae and

a higher macrophytes coverage could increase the free TAA content in wild mitten crabs, while

polluted environments would negatively affect protein efficiency ratio and chemical composition.

Hussain et al. (2018) reported that loss in the nutritional value in fish harvested from polluted

sections of the River Chenab. Dietary protein had a significant effect on whole-body crude protein

and muscle amino acid profile (Yu et al, 2019). Individual and total EAAs significantly increased

312 when the dietary protein levels increased from $31.6 \%$ to $50.2 \%$ (Jin et al, 2013). Trash fish as a

313 high protein feed is usually operated in the mitten crab culture. In our study, the ratio of trash fish 
314 to total feed in ranged from $53 \%$ to $78 \%$ in the south area of Jiangsu Province (Gaochun, Jintan

315 and Suzhou), being much higher than that in other areas (11\%-51\%) (Refer to Fig. 3F).

316 Accordingly, the crab muscle EAA contents were higher in sites with high trash fish input. In fact,

317 the trash fish as feed in aquaculture have been banned in China in recent years, mainly due to

318 potential environmental pollution. But according to the survey from 156 crab farms around

319 Hongzehu Lake, Wang et al. (2016b) did not find significant differences in total nitrogen and total

320 phosphorus loading among feed types. They argued that use of plants and filter-feeding snails

321 could help maintain good water quality.

323 Conclusion

324 In order to explain how the farming operations affected the amino acids composition of

325 Chinese mitten crabs, crabs were collected and farming practices were investigated from 7 main

326 farming areas in Jiangsu Province. The results showed that significant differences in farming

327 practices and amino acids content of three edible tissues among the pond-reared male and female

328 mitten crabs across Jiangsu Province. Higher snail supply, macrophytes coverage, total

329 commercial feed, and the ratio of trash fish to total feed input in the south area of Jiangsu Province

330 (Gaochun and Jintan) lead to higher average individual body weight, higher commercial yields

331 and altered the amino acid content and structure. The crabs collected delivered high nutrient value

332 (AAS $>1$ except Val) with Glu, Asp, and Ala as the main amino acids contained. The muscle EAA

333 contents in Gaochun, Jintan, Suzhou and Guannan were significantly higher those in other sites.

334 The research suggests that the Chinese mitten crab is healthy for human consumption and the trash 
335 fish feed and snail would influence the amino acids composition of crabs and taste. Maybe more

336 sample collections could support the results strongly. Further studies should elucidate how the

337 trash fish feed and snail affect the nutrient value and whether insect source protein can be used as

338 an alternative feed in crab aquaculture based on experimental investigations. Such studies may

339 provide credible guidance to farmers on how to obtain high nutrient values of mitten crab culture

340 and much deeper understanding of how the feeds affect the quality.

341

342

343 Acknowledgements

344 We thank Anne Mette Poulsen for critical editorial assistance and Prof. Ma Ronghua for map 345

rendering of Jiangsu Province. This work was supported by the National Key Research and

Development Program of China (2020YFD0900500), the Natural Science Foundation of China

(No. 31972813) and the Jiangsu Province Scientific Research Foundation (TH2018303 \& CX(20)2026). EJ was supported by the Tübitak Outstanding Researcher Program (BIDEB 2232 \&

Project 118C250).

350

\section{References}

Abol-Munafi AB, Mukrim MS, Amin RM, Azra MN, Azmie G, Ikhwanuddin M. 2016.

Histological profile and fatty acid composition in hepatopancreas of blue swimming crab,

Portunus pelagicus (Linnaeus, 1758) at different ovarian maturation stages. Turkish Journal of 
356 Akiyama T, Oohara I, Yamamoto T. 1997. Comparison of essential amino acid requirements with

357 A/E ratio among fish species. Fisheries Science 63: 963-970

358 Azarm HM, Lee SM. 2014. Effects of partial substitution of dietary fish meal by fermented

359 soybean meal on growth performance, amino acid and biochemical parameters of juvenile black

360 sea bream. Aquatic Research 45(6): 994-1003

361 Barrento S, Marques A, Teixeira B, Vaz-Pires P, Nunes ML. 2009. Nutritional quality of the edible

362 tissues of European lobster Homarus gammarus and American lobster Homarus americanus.

363 Journal of Agricultural and Food Chemistry 57 (9): 3645-3652

364 Barrento S, Marques A, Teixeira B, Mendes R, Bandarra N, Vaz-Pires P, Nunes ML. 2010.

365 Chemical composition, cholesterol, fatty acid and amino acid in two populations of brown crab

366 Cancer pagurus: Ecological and human health implications. Journal of Food Composition and 367 Analysis 23: 716-725

368 Butts IAE, Hilmarsdottir GS, Zadmajid V, Gallego V, Støttrup JG, Jacobsen C, Kruger-Johnsen

M, Politis SN, Asturiano JF, Holst LK, Tomkiewicz J. 2020. Dietary amino acids impact sperm

performance traits for a catadromous fish, Anguilla anguilla reared in captivity. Aquaculture 518:

734602

372 Chen DW, Zhang M, Shrestha S. 2007. Compositional characteristics and nutrition quality of

373 Chinese mitten crab (Eriocheir sinensis). Food Chemistry 103: 1343-1349

374 Chen T. 2008. An analysis of environmental sociology on the mode of crab cultivation: from

pursuing quantity to pursuing quality: A case study of Xing Village in China. Journal of Hohai

University (Philosophy and Social Sciences) 10(4): 25-29, 95 (In Chinese with English abstract)

Peer) reviewing PDF | (2020:09:52682:4:0:NEW 17 May 2021) 
377 China Fishery Statistics Yearbook. 2019. Beijing, China: Bureau of Fisheries, Ministry of 378 Agriculture, 24

379 FAO/WHO. 1991. Protein quality evaluation report of joint FAO/WHO expert consultation, Food 380 and Agriculture Organization of the United Nations. Rome: FAO food and nutrition paper 51: 247 Fishery and fishery administration of the Ministry of agriculture and rural areas. 2019. China Fisheries Statistics Yearbook (CFSY). China Agriculture Press: 24 (In Chinese)Guo YR, Gu SQ, Wang XC, Zhao LM, Zheng JY. 2014. Comparison of fatty acid and amino acid profiles of steamed Chinese mitten crab. Fisheries Science 80: 621-633

He J, Xuan FJ, Shi H, Xie JJ, Wang W, Wang GS, Xu WJ. 2017. Comparison of nutritional quality of three edible tissues of the wild-caught and pond-reared swimming crab (Portunus trituberculatus) females. LWT- Food Science and Technology, 75, 624-630

Hussain B, Sultana T, Sultana S, Ahmed Z, Mahboob S. 2018. Study on impact of habitat degradation on proximate composition and amino acid profile of Indian major carps from different habitats. Saudi Journal of Biological Sciences 25: 755-759

Jin M, Zhou QC, Zhang W, Xie FJ, ShenTu JK, Huang XL. 2013. Dietary protein requirements of the juvenile swimming crab, Portunus trituberculatus. Aquaculture 414-415: 303-308

Kasozi N, Iwe G, Sadik K, Asizua D, Namulawa VT. 2019. Dietary amino acid requirements of pebbly fish, Alestes baremoze (Joannis, 1835) based on whole body amino acid composition. Aquaculture Reports 14: 100197

Kong L, Cai C, Ye Y, Chen D, Wu P, Li E, Song L. 2012. Comparison of non-volatile compounds 
Aquaculture 364-365: 96-102

399

400

401

402

403

404

405

406

407

408

409

410

411

412

413

414

415

416

417

418

Latuihamallo M, Iriana D, Apituley D. 2015. Amino acid and fatty acid of abalone Haliotis

squamata cultured in different aquaculture systems. Procedia Food Science 3: 174-181

Liu CS, Meng FT, Tang XM, Shi YH, Wang AM, Gu ZF, Pan Z. 2018. Comparison of nonvolatile

taste active compounds of wild and cultured mud crab Scylla paramamosain. Fisheries Science

84: 897-907

Liu JD, Chi C, Zheng XC, Xu CY, Zhang CY, Ye MW, Liu WB. 2019. Effect of dietary glutathione supplementation on the immune responses and the fatty acid and amino acid composition in Chinese mitten crab, Eriocheir sinensis. Aquaculture Reports 15: 100217

Muhammad T, Ismail S, Ikhwanuddin M, Abol-Munafi AB. 2019. Experimental data on behavioral, hepatosomatic, gonadosomatic indexes and total lipid of mud crab, Scylla olivacea at different velocity levels. Data in brief 25: 104205

Sharawy Z, Goda AS, Hassaan MS. 2016. Partial or total replacement of fish meal by solid state fermented soybean meal with Saccharomyces cerevisiae in diets for Indian prawn shrimp, Fenneropenaeus indicus, Postlarvae. Animal Feed Science and Technology 212: 90-99

Wang QD, Li ZJ, Lian YX, Du X, Zhang SY, Yuan J, Liu JS, Silva SSD. 2016a. Farming system transformation yields significant reduction in nutrient loading: Case study of Hongze Lake, Yangtze River Bason, China. Aquaculture 457: 109-117

Wang QD, Liu JS, Zhang SY, Lian YX, Ding HY, Du X, Li ZJ, Silva SSD. 2016b. Sustainable farming practices of Chinese mitten crab (Eriocheir sinensis) around Hongze Lake, lower Yangtze River Basin, China. Ambio 45: 361-373 
419 Wang S, He Y, Wang YY, Tao NP, Wu XG, Wang XC, Qiu WQ, Ma MJ. 2016c. Comparison of

420 flavor qualities of three sourced Eriocheir sinensis. Food Chemistry 200: 24-31

421 Wu HR, Ge MT, Chen HF, Jiang ST, Lin L, Lu JF. 2020. Comparison between the nutritional 422 qualities of wild-caught and rice-field male Chinese mitten crabs (Eriocheir sinensis). LWT - Food 423 Science and Technology 117: 108663

424 Wu QY, Waiho K, Huang Z, Li SK, Zheng HP, Zhang YL, Ikhwanuddin M, Lin F, Ma HY. 2020.

425 Growth performance and biochemical composition dynamics of ovary, hepatopancreas and muscle 426 tissues at different ovarian maturation stages of female mud crab, Scylla paramamosain. Aquaculture 515: 734560

Wang QJ, Wu XG, Long XW, Zhu WL, Ma TL, Chen YX. 2018. Nutritional quality of different grades of adult male Chinese mitten crab, Eriocheir sinensis. Journal of Food Science and

Technology 55(3): 944-955

Xu CY, Liu WB, Zhang DD, Liu JD, Zheng XC, Zhang CY, Yao JG, Zhu CM, Chi C. 2020.

Effects of partial fish meal replacement with two fermented soybean meals on the growth of and protein metabolism in the Chinese mitten crab (Eriocheir sinensis). Aquaculture Reports 17: 100328

Yamaguchi S, Yoshikawa T, Ikeda S, Ninomiya T. 1971. Measurement of the relative taste intensity of some a-amino acid and 5'-nucleotides. Journal of Food Science 36: 846-849

Yu JY, Yu J, Chen XM, Zhou X, Cai YX, Cai HY, Yan PS. 2019. Effects of fermented protein feed on the growth performance of pond-raised crab. Aquaculture and Fisheries 4: 149-155 
440 with cottonseed meal protein hydrolysate affects amino acid metabolism via AMPK/SIRT1 and

441 TOR signaling pathway of Megalobrama amblycephala. Aquaculture 510: 225-233

442 Zeng QF, Jeppesen E, Gu XH, Mao ZG, Chen HH. 2018. Cannibalism and habitat selection of

443 cultured Chinese mitten crab: Effects of submerged aquatic vegetation with different nutritional

444 and refuge values. Water 10: 1542

445 
Figure 1

A schematic overview of the study. $n=$ number of sample replicates for amino acid analysis. 


\section{Activities at crab pond}

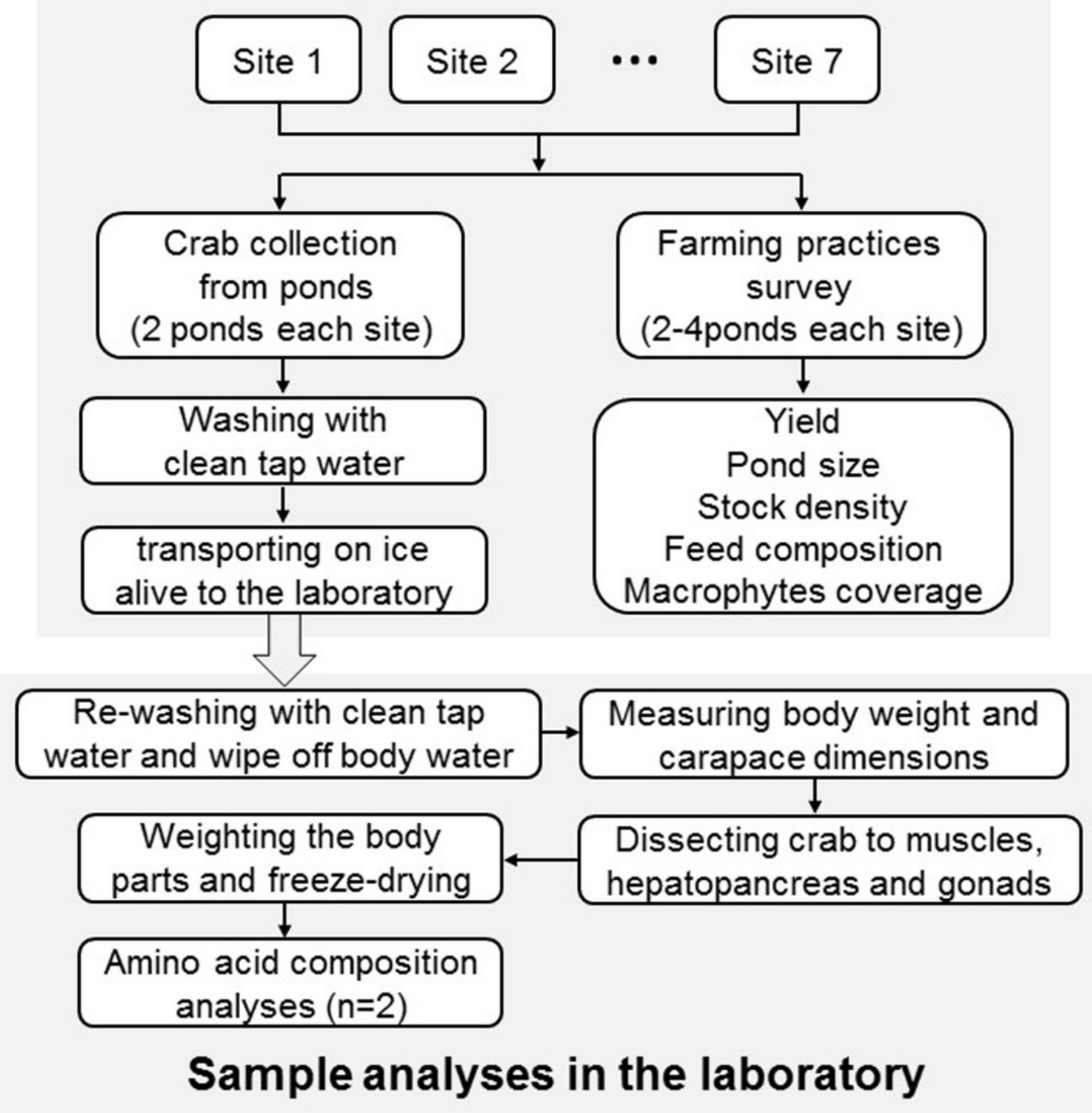


Figure 2

Location of Jiangsu Province and sampling sites of Chinese mitten crab (Eriocheir sinensis Milne Edwards, 1853).

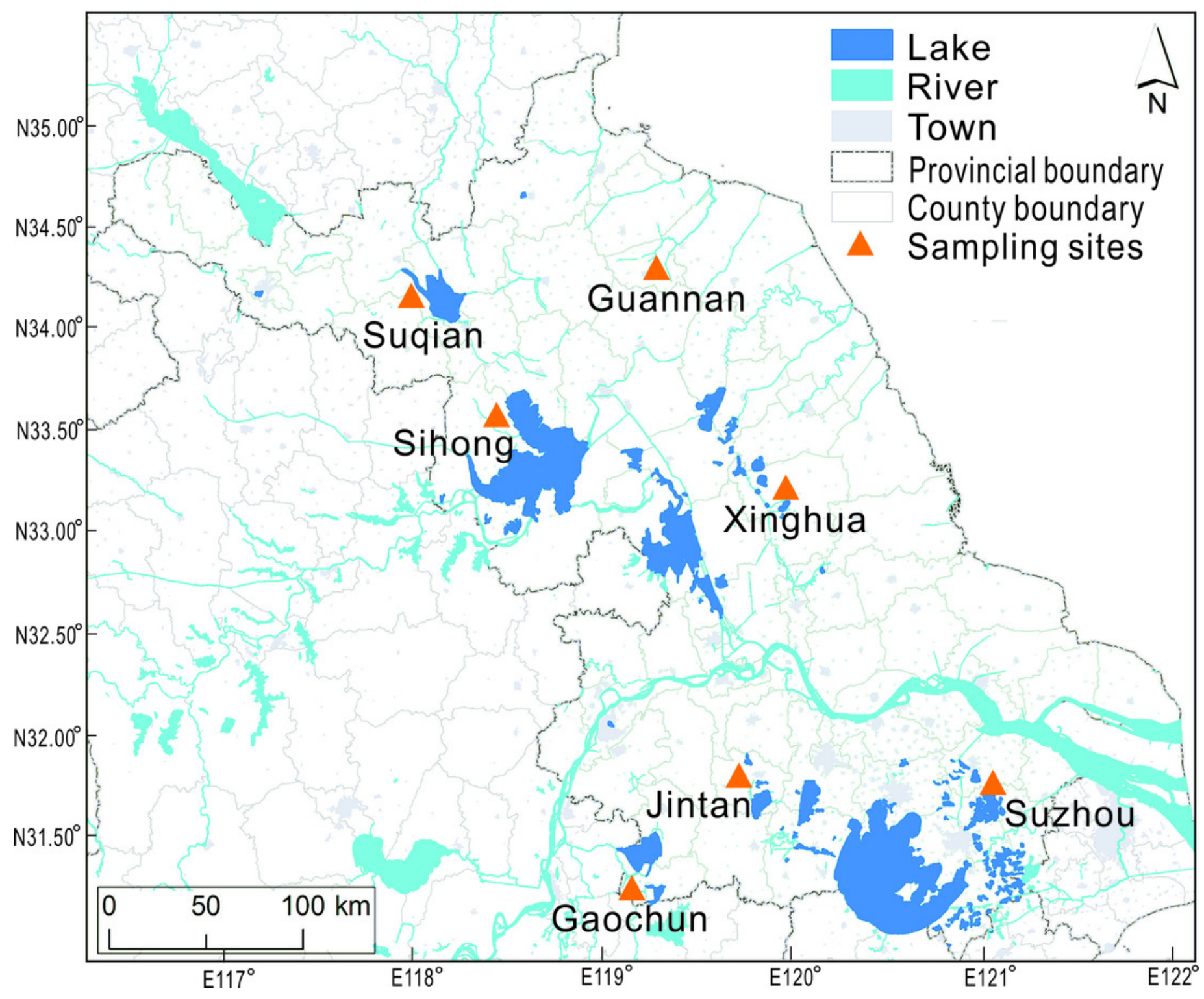


Figure 3

Farming practice differences of Chinese mitten crab in Jiangsu Province.

SQ, Suqian; GN, Guannan; SH, Sihong; XH, Xinghua; GC, Gaochun; JT, Jintan; SZ, Suzhou. 

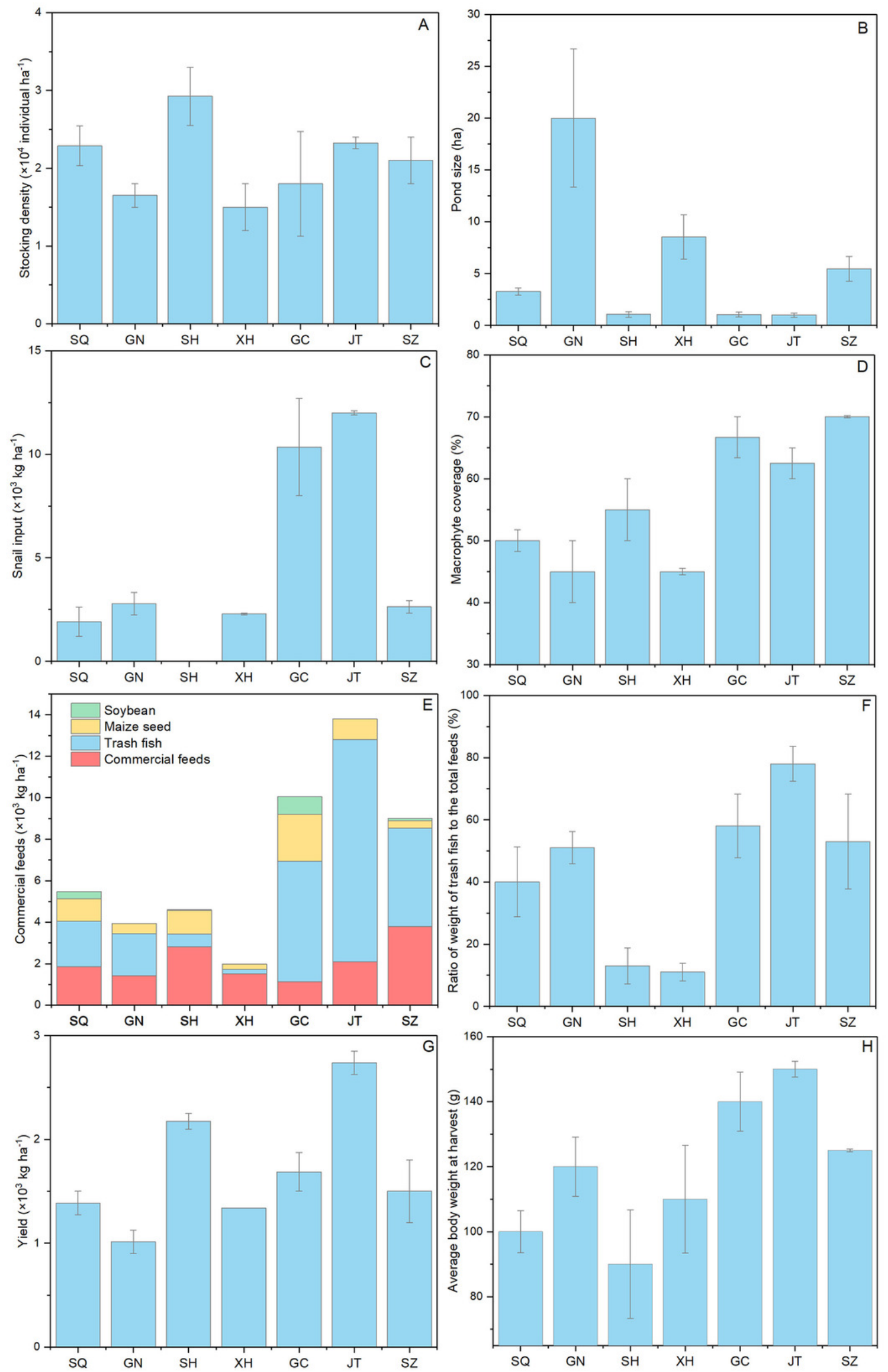
Figure 4

RDA plots of ordination between farming practices and sampling sites $(A)$, amino acids composition (B).

(A) Ordination between farming practices and sampling sites; (B) Ordination between farming practices and amino acids composition.
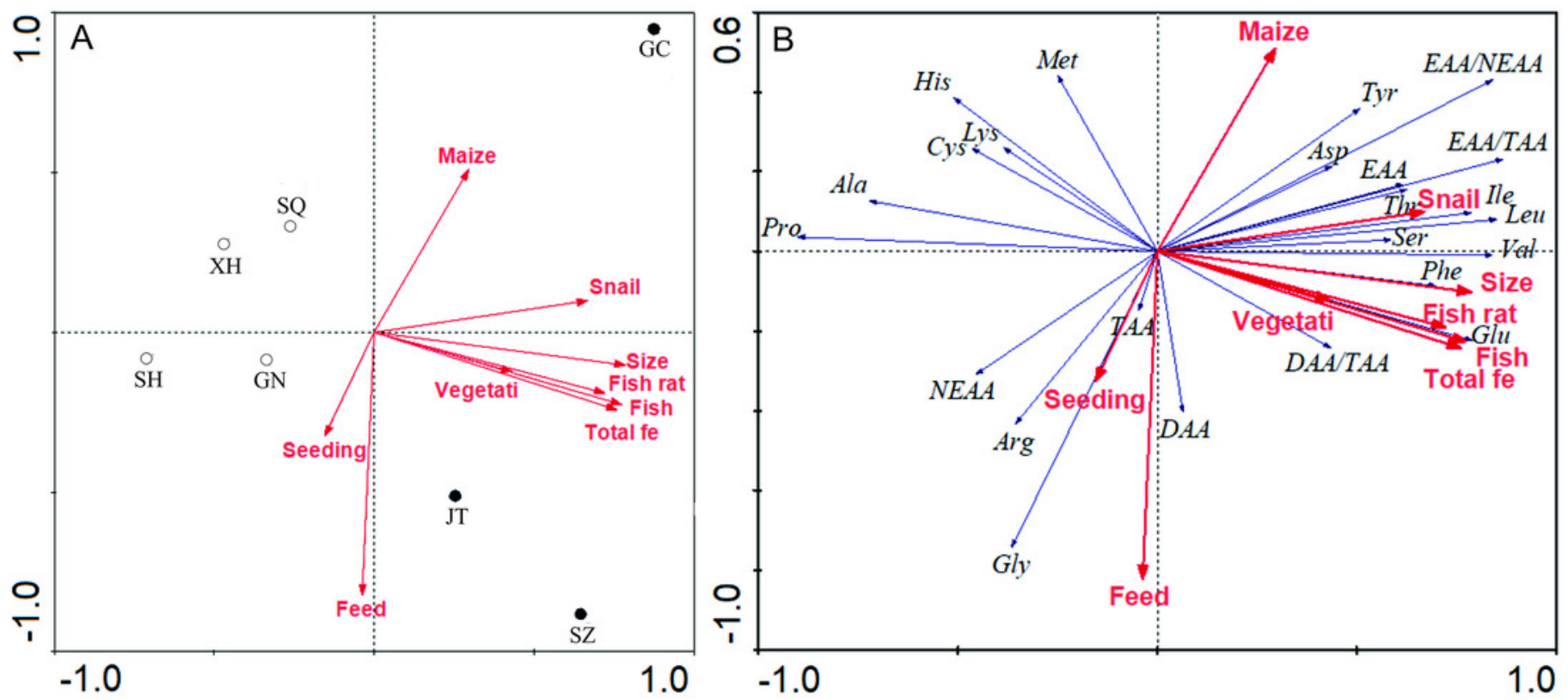


\section{Figure 5}

NMDS results of mitten crab from different sampling sites based on Bray-Curtis similarities calculated from amino acid concentration. A, Muscle; B, hepatopancreas; C, gonad.

GC, Gaochun; SZ, Suzhou; JT, Jintan; XH, Xinghua; GN, Guannan; SH, Sihong; SQ, Suqian. Significant differences in muscle amino acids (A) were found between southern jiangsu (JT, SZ and GC in pink (\$) and orange ( $\left.\sigma^{\top}\right)$ triangle) and northern Jiangsu (GN, XH and SH in gray (९) and blue ( $\left.\sigma^{\top}\right)$ triangle), but gender differences in southern Jiangsu ( $p=0.1024, \mathbf{J T}, \mathbf{S Z}$ and GC in pink (\$) vs. orange ( $\left.\sigma^{*}\right)$ triangle) are not significant, nor in northern Jiangsu ( $p=0.7731$, GN, XH and SH in gray (\$) vs. blue ( $\left.\sigma^{\top}\right)$ triangle). Only gender differences were found in gonad amino acids (C) $\left(p=0.0289\right.$, males in all sites in orange $\left(\sigma^{7}\right)$ and blue $\left(\sigma^{7}\right)$ triangle vs. female in all sites in pink (\$) and gray (\$) triangle). Neither sites or gender differences were found in hepatopancreas amino acids (B).
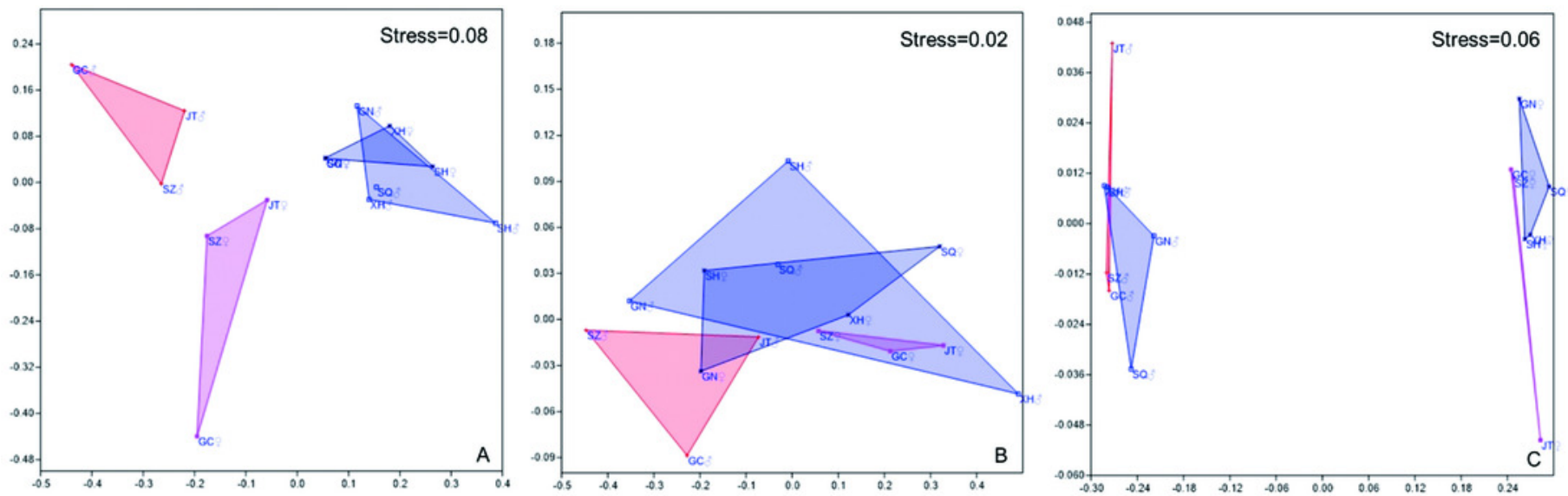


\section{Table 1 (on next page)}

Growth and tissue indices of Chinese mitten crab in Jiangsu Province (means \pm SE)

Different letters represent significant differences among sites for $p<0.05 . C L$, carapace length; CW carapace width; HSI, hepatopancreas index; GSI, gonadosomatic index; GH ratio, the ratio of gonad to hepatopancreas; CF, condition factor. 


\section{$1 \quad$ Table 1}

2 Growth and tissue indices of Chinese mitten crab in Jiangsu Province (means \pm SE)

\begin{tabular}{|c|c|c|c|c|c|c|c|c|c|c|c|c|c|c|}
\hline & \multicolumn{2}{|c|}{ Suqian } & \multicolumn{2}{|c|}{ Guannan } & \multicolumn{2}{|c|}{ Sihong } & \multicolumn{2}{|c|}{ Xinghua } & \multicolumn{2}{|c|}{ Gaochun } & \multicolumn{2}{|c|}{ Jintan } & \multicolumn{2}{|c|}{ Suzhou } \\
\hline & $\hat{0}$ & 우 & $\sigma^{\lambda}$ & 우 & $\hat{0}$ & 우 & $\hat{0}$ & 우 & $\hat{o}$ & 우 & $\hat{0}$ & 우 & $\partial$ & 우 \\
\hline $\begin{array}{c}\text { Body } \\
\text { weight } g\end{array}$ & $135.34 \pm 4.66 \mathrm{c}$ & $104.46 \pm 8.14 \mathrm{c}$ & $137.45 \pm 5.37 \mathrm{~d}$ & $73.38 \pm 2.27 \mathrm{~d}$ & $128.96 \pm 5.73 \mathrm{c}$ & $97.42 \pm 3.06 \mathrm{c}$ & $155.26 \pm 1.95 \mathrm{c}$ & $80.94 \pm 1.63 \mathrm{c}$ & $151.34 \pm 6.93 b$ & $123.4 \pm 8.95 b$ & $198.62 \pm 4.66 \mathrm{a}$ & $125.08 \pm 2.92 \mathrm{a}$ & $147.64 \pm 4.83 \mathrm{c}$ & $103.58 \pm 3.78 \mathrm{c}$ \\
\hline $\begin{array}{l}\text { Muscle } \\
\text { weight g }\end{array}$ & $19.26 \pm 1.07 \mathrm{~d}$ & $17.1 \pm 2.60 \mathrm{~d}$ & $19.30 \pm 0.93 \mathrm{ed}$ & $11.5 \pm 1.43 \mathrm{ed}$ & $19.68 \pm 0.65 \mathrm{~d}$ & $17.3 \pm 0.66 \mathrm{~d}$ & $20.94 \pm 1.6 \mathrm{~d}$ & $13.12 \pm 1.06 \mathrm{~d}$ & $30.64 \pm 1.75 b$ & $19.44 \pm 1.1 \mathrm{~b}$ & $43.06 \pm 1.68 \mathrm{a}$ & $21.34 \pm 0.92 \mathrm{a}$ & $26.60 \pm 2.08 \mathrm{c}$ & $17.52 \pm 1.42 \mathrm{c}$ \\
\hline $\mathrm{CL} \mathrm{cm}$ & $5.84 \pm 0.19 \mathrm{c}$ & $5.70 \pm 0.22 \mathrm{c}$ & $6.10 \pm 0.07 \mathrm{c}$ & $5.25 \pm 0.05 \mathrm{c}$ & $5.96 \pm 0.08 \mathrm{c}$ & $5.72 \pm 0.07 \mathrm{c}$ & $6.22 \pm 0.07 \mathrm{c}$ & $5.38 \pm 0.04 \mathrm{c}$ & $6.30 \pm 0.23 \mathrm{~b}$ & $6.0 \pm 0.27 \mathrm{~b}$ & $6.90 \pm 0.05 \mathrm{a}$ & $6.31 \pm 0.07 \mathrm{a}$ & $6.26 \pm 0.07 \mathrm{bc}$ & $5.82 \pm 0.1 \mathrm{bc}$ \\
\hline $\mathrm{CW} \mathrm{cm}$ & $6.36 \pm 0.16 \mathrm{c}$ & $6.1 \pm 0.17 \mathrm{c}$ & $6.55 \pm 0.06 \mathrm{~cd}$ & $5.53 \pm 0.05 \mathrm{~cd}$ & $6.37 \pm 0.10 \mathrm{c}$ & $6.08 \pm 0.13 \mathrm{c}$ & $6.7 \pm 0.09 \mathrm{c}$ & $5.68 \pm 0.08 \mathrm{c}$ & $6.92 \pm 0.19 \mathrm{~b}$ & $6.2 \pm 0.25 \mathrm{~b}$ & $7.42 \pm 0.02 \mathrm{a}$ & $6.55 \pm 0.05 \mathrm{a}$ & $6.66 \pm 0.06 \mathrm{bc}$ & $6.20 \pm 0.08 b c$ \\
\hline HSI\% & $8.22 \pm 0.37 \mathrm{ab}$ & $8.27 \pm 0.49 \mathrm{ab}$ & $8.14 \pm 0.41 \mathrm{a}$ & $9.42 \pm 0.63 \mathrm{a}$ & $7.37 \pm 0.39 \mathrm{~b}$ & $7.00 \pm 0.46 \mathrm{~b}$ & $8.66 \pm 0.40 \mathrm{a}$ & $9.12 \pm 0.47 \mathrm{a}$ & $6.65 \pm 0.4 \mathrm{~b}$ & $8.25 \pm 0.59 \mathrm{~b}$ & $7.58 \pm 0.45 b$ & $7.25 \pm 0.28 b$ & $6.67 \pm 0.41 \mathrm{~b}$ & $7.06 \pm 0.33 b$ \\
\hline GSI $\%$ & $2.95 \pm 0.16 \mathrm{bc}$ & $8.41 \pm 0.15 \mathrm{bc}$ & $2.45 \pm 0.28 \mathrm{bc}$ & $8.91 \pm 0.93 b c$ & $2.91 \pm 0.25 \mathrm{ab}$ & $8.89 \pm 0.39 \mathrm{ab}$ & $2.97 \pm 0.22 \mathrm{ab}$ & $8.93 \pm 0.23 \mathrm{ab}$ & $2.16 \pm 0.18 \mathrm{a}$ & $11.67 \pm 1.05 \mathrm{a}$ & $2.67 \pm 0.29 \mathrm{ab}$ & $10.99 \pm 0.59 \mathrm{ab}$ & $2.61 \pm 0.51 \mathrm{abc}$ & $10.28 \pm 0.35 \mathrm{abc}$ \\
\hline GH ratio & $0.36 \pm 0.03 \mathrm{bc}$ & $1.03 \pm 0.04 \mathrm{bc}$ & $0.30 \pm 0.03 \mathrm{c}$ & $0.97 \pm 0.14 \mathrm{c}$ & $0.39 \pm 0.03 \mathrm{ab}$ & $1.29 \pm 0.10 \mathrm{ab}$ & $0.35 \pm 0.04 \mathrm{c}$ & $0.99 \pm 0.08 \mathrm{c}$ & $0.33 \pm 0.02 \mathrm{a}$ & $1.42 \pm 0.09 \mathrm{a}$ & $0.36 \pm 0.11 \mathrm{a}$ & $1.53 \pm 0.11 \mathrm{a}$ & $0.41 \pm 0.09 \mathrm{a}$ & $1.47 \pm 0.09 \mathrm{a}$ \\
\hline $\mathrm{CF}$ & $0.69 \pm 0.06 \mathrm{a}$ & $0.56 \pm 0.02 \mathrm{a}$ & $0.60 \pm 0.01 \mathrm{ab}$ & $0.51 \pm 0.00 \mathrm{ab}$ & $0.61 \pm 0.03 \mathrm{ab}$ & $0.52 \pm 0.01 \mathrm{ab}$ & $0.65 \pm 0.02 \mathrm{ab}$ & $0.52 \pm 0.01 \mathrm{ab}$ & $0.61 \pm 0.04 \mathrm{a}$ & $0.58 \pm 0.04 \mathrm{a}$ & $0.60 \pm 0.02 \mathrm{ab}$ & $0.50 \pm 0.02 \mathrm{ab}$ & $0.60 \pm 0.01 \mathrm{ab}$ & $0.53 \pm 0.02 \mathrm{ab}$ \\
\hline
\end{tabular}

3 Different letters represent significant differences among sites for $p<0.05$.

4 CL, carapace length; CW carapace width; HSI, hepatopancreas index; GSI, gonadosomatic index; GH ratio, the ratio of gonad to

5 hepatopancreas; $\mathrm{CF}$, condition factor. 


\section{Table 2 (on next page)}

Main and interactive effects of sampling sites and sex on body weight, muscle, $\mathrm{CL}, \mathrm{CW}$, $\mathrm{HSI} \%, \mathrm{GSI} \%$, GH ratio and CF.

$\mathrm{CL}$, carapace length; CW carapace width; $\mathrm{HSI}$, hepatopancreas index; GSI, gonadosomatic index; GH ratio, the ratio of gonad to hepatopancreas; CF, condition factor. 
Table 2 Main and interactive effects of sampling sites and sex on body weight, muscle, $\mathrm{CL}, \mathrm{CW}, \mathrm{HSI} \%$, GSI\%, GH ratio and $\mathrm{CF}$.

\begin{tabular}{cccccccc}
\hline \multirow{2}{*}{ Measurement } & \multicolumn{2}{c}{ Sampling sites } & \multicolumn{2}{c}{ sex } & \multicolumn{2}{c}{ Interaction } & \multirow{2}{*}{$R^{2}$} \\
\cline { 2 - 7 } & $F(6,12)$ & $p$ & $F(1,12)$ & $p$ & $F(5,12)$ & $p$ & \\
\hline Body weight & 25.67 & 0.000 & 316.14 & 0.000 & 8.04 & 0.000 & 0.905 \\
Muscle & 31.19 & 0.000 & 126.62 & 0.000 & 10.28 & 0.000 & 0.875 \\
& & & & & & & \\
weight & & & & & & & \\
CL & 10.46 & 0.000 & 42.21 & 0.000 & 2.02 & 0.079 & 0.681 \\
CW & 11.87 & 0.000 & 91.90 & 0.000 & 3.19 & 0.009 & 0.769 \\
HSI\% & 6.56 & 0.000 & 3.48 & 0.067 & 1.49 & 0.200 & 0.488 \\
GSI\% & 2.49 & 0.034 & 783.29 & 0.000 & 5.12 & 0.000 & 0.939 \\
GH ratio & 5.89 & 0.000 & 491.89 & 0.000 & 4.55 & 0.001 & 0.913 \\
CF & 2.19 & 0.058 & 47.64 & 0.000 & 0.79 & 0.584 & 0.549 \\
\hline
\end{tabular}

CL, carapace length; CW carapace width; HSI, hepatopancreas index; GSI, gonadosomatic index; $\mathrm{GH}$ ratio, the ratio of gonad to hepatopancreas; $\mathrm{CF}$, condition factor 


\section{Table 3(on next page)}

Amino acid concentration ( $100 \mathrm{~g}^{-1}$ of dry weight) comparison between tissues of crabs from location and sexes (means $\pm \mathrm{SE}$ ).

Different letters represent significant differences among sites for $p<0.05$. Asp, Aspartic acid; Thr, Threonine; Ser, Serine; Glu, Glutamic acid; Gly, Glycine; Ala, Alanine; Cys, Cystine; Val, Valine; Met, Methionine; Ile, Isoleucine; Leu, Leucine; Tyr, Tyrosine; Phe, Phenylalanine; Lys, Lysine; His, Histidine; Arg, Arginine; Pro, Proline. TAA, total amino acids; EAA, essential amino acids; NEAA, non-essential amino acids; DAA, delicious amino acids; EAA/TAA, essential amino acids/total amino acids. 
1 Table 2

2 Amino acid concentration (g $100 \mathrm{~g}^{-1}$ of dry weight) comparison between tissues of crabs from

3 location and sexes (means $\pm \mathrm{SE})$.

\begin{tabular}{lllll}
\hline & Muscle & Hepatopancreas & Gonads & $p$ \\
\hline Asp & $7.2 \pm 0.1 \mathrm{a}$ & $1.11 \pm 0.04 \mathrm{~b}$ & $5.98 \pm 0.31 \mathrm{a}$ & 0.000 \\
Thr & $3.5 \pm 0.03 \mathrm{a}$ & $0.61 \pm 0.03 \mathrm{~b}$ & $4.11 \pm 0.30 \mathrm{a}$ & 0.000 \\
Ser & $2.93 \pm 0.0 \mathrm{a}$ & $0.47 \pm 0.02 \mathrm{~b}$ & $3.01 \pm 0.04 \mathrm{a}$ & 0.000 \\
Glu & $11.12 \pm 0.14 \mathrm{a}$ & $1.32 \pm 0.05 \mathrm{c}$ & $7.28 \pm 0.14 \mathrm{~b}$ & 0.000 \\
Gly & $4.88 \pm 0.09 \mathrm{a}$ & $0.61 \pm 0.03 \mathrm{c}$ & $2.27 \pm 0.03 \mathrm{~b}$ & 0.000 \\
Ala & $6.63 \pm 0.11 \mathrm{a}$ & $0.80 \pm 0.04 \mathrm{c}$ & $4.02 \pm 0.18 \mathrm{~b}$ & 0.000 \\
Cys & $1.27 \pm 0.03 \mathrm{a}$ & $0.23 \pm 0.02 \mathrm{~b}$ & $1.26 \pm 0.09 \mathrm{a}$ & 0.000 \\
Val & $3.15 \pm 0.04 \mathrm{a}$ & $0.58 \pm 0.02 \mathrm{c}$ & $2.60 \pm 0.16 \mathrm{~b}$ & 0.000 \\
Met & $1.95 \pm 0.03 \mathrm{a}$ & $0.26 \pm 0.01 \mathrm{c}$ & $1.07 \pm 0.15 \mathrm{~b}$ & 0.000 \\
Ile & $3.25 \pm 0.04 \mathrm{a}$ & $0.47 \pm 0.02 \mathrm{c}$ & $2.65 \pm 0.03 \mathrm{~b}$ & 0.000 \\
Leu & $5.53 \pm 0.07 \mathrm{a}$ & $0.82 \pm 0.03 \mathrm{c}$ & $4.09 \pm 0.05 \mathrm{~b}$ & 0.000 \\
Tyr & $2.95 \pm 0.03 \mathrm{a}$ & $0.36 \pm 0.03 \mathrm{c}$ & $2.08 \pm 0.06 \mathrm{~b}$ & 0.000 \\
Phe & $3.14 \pm 0.04 \mathrm{a}$ & $0.56 \pm 0.03 \mathrm{c}$ & $2.35 \pm 0.07 \mathrm{~b}$ & 0.000 \\
Lys & $5.60 \pm 0.07 \mathrm{a}$ & $0.71 \pm 0.03 \mathrm{c}$ & $3.11 \pm 0.09 \mathrm{~b}$ & 0.000 \\
His & $1.58 \pm 0.02 \mathrm{a}$ & $0.27 \pm 0.01 \mathrm{c}$ & $1.25 \pm 0.05 \mathrm{~b}$ & 0.000 \\
Arg & $6.89 \pm 0.13 \mathrm{a}$ & $0.78 \pm 0.04 \mathrm{c}$ & $3.12 \pm 0.18 \mathrm{~b}$ & 0.000 \\
Pro & $3.56 \pm 0.14 \mathrm{a}$ & $0.57 \pm 0.04 \mathrm{~b}$ & $4.98 \pm 0.73 \mathrm{a}$ & 0.000 \\
TAA & $75.09 \pm 0.43 \mathrm{a}$ & $10.52 \pm 0.47 \mathrm{c}$ & $55.20 \pm 1.09 \mathrm{~b}$ & 0.000 \\
EAA & $26.12 \pm 0.21 \mathrm{a}$ & $4.00 \pm 0.17 \mathrm{c}$ & $19.97 \pm 0.20 \mathrm{~b}$ & 0.000 \\
NEAA & $48.97 \pm 0.32 \mathrm{a}$ & $6.52 \pm 0.30 \mathrm{c}$ & $35.23 \pm 1.21 \mathrm{~b}$ & 0.000 \\
DAA & $29.80 \pm 0.19 \mathrm{a}$ & $3.84 \pm 0.17 \mathrm{c}$ & $19.54 \pm 0.61 \mathrm{~b}$ & 0.000 \\
EAA/TAA & $0.35 \mathrm{~b}$ & $0.38 \mathrm{a}$ & $0.37 \pm 0.01 \mathrm{a}$ & 0.000 \\
\hline & & & & \\
\hline
\end{tabular}

4 Different letters represent significant differences among sites for $p<0.05$.

5 Asp, Aspartic acid; Thr, Threonine; Ser, Serine; Glu, Glutamic acid; Gly, Glycine; Ala, Alanine;

6 Cys, Cystine; Val, Valine; Met, Methionine; Ile, Isoleucine; Leu, Leucine; Tyr, Tyrosine; Phe,

7 Phenylalanine; Lys, Lysine; His, Histidine; Arg, Arginine; Pro, Proline. TAA, total amino acids;

8 EAA, essential amino acids; NEAA, non-essential amino acids; DAA, delicious amino acids;

9 EAA/TAA, essential amino acids/total amino acids. 


\section{Table 4 (on next page)}

Amino acid concentration ( $\mathrm{g} 100 \mathrm{~g}^{-1}$ of dry weight) of mitten crab muscle from each site and sex (mean $\pm \mathrm{SE})$.

Different letters represent significant differences among sites for $p<0.05$. Asp, Aspartic acid; Thr, Threonine; Ser, Serine; Glu, Glutamic acid; Gly, Glycine; Ala, Alanine; Cys, Cystine; Val, Valine; Met, Methionine; Ile, Isoleucine; Leu, Leucine; Tyr, Tyrosine; Phe, Phenylalanine; Lys, Lysine; His, Histidine; Arg, Arginine; Pro, Proline. TAA, total amino acids; EAA, essential amino acids; NEAA, non-essential amino acids; DAA, delicious amino acids; EAA/TAA, essential amino acids/total amino acids. 


\section{$1 \quad$ Table 3}

2 Amino acid concentration (g $100 \mathrm{~g}^{-1}$ of dry weight) of mitten crab muscle from each site and sex (mean $\pm \mathrm{SE}$ ).

\begin{tabular}{|c|c|c|c|c|c|c|c|c|c|c|c|c|c|c|c|c|c|}
\hline & \multicolumn{2}{|c|}{ Suqian } & \multicolumn{2}{|c|}{ Guannan } & \multicolumn{2}{|c|}{ Sihong } & \multicolumn{2}{|c|}{ Xinghua } & \multicolumn{2}{|c|}{ Gaochun } & \multicolumn{2}{|c|}{ Jintan } & \multicolumn{2}{|c|}{ Suzhou } & \multicolumn{3}{|c|}{ Effect test, $p$} \\
\hline & $\sigma^{\lambda}$ & 우 & $\sigma^{\lambda}$ & 우 & ๙ & 우 & ๙ & 우 & $\hat{0}$ & 우 & $\hat{0}$ & 우 & $\hat{\sigma}$ & 우 & Location & Sex & Location $\times$ Sex \\
\hline Asp & $6.99 \pm 0.17 \mathrm{ab}$ & $7.3 \pm 0.2 \mathrm{ab}$ & $7.27 \pm 0.02 \mathrm{a}$ & $7.3 \pm 0.1 \mathrm{a}$ & $6.69 \pm 0.08 \mathrm{~b}$ & $7.04 \pm 0.04 \mathrm{~b}$ & $7.1 \pm 0.2 \mathrm{ab}$ & $7.23 \pm 0.05 \mathrm{ab}$ & $7.44 \pm 0.04 \mathrm{a}$ & $7.2 \pm 0.2 \mathrm{a}$ & $7.32 \pm 0.03 \mathrm{a}$ & $7.24 \pm 0.02 \mathrm{a}$ & $7.16 \pm 0.03 \mathrm{ab}$ & $7.05 \pm 0.02 \mathrm{ab}$ & 0.017 & 0.366 & 0.142 \\
\hline Thr & $3.47 \pm 0.07 \mathrm{a}$ & $3.56 \pm 0.04 \mathrm{a}$ & $3.52 \pm 0.03 \mathrm{a}$ & $3.51 \pm 0.04 \mathrm{a}$ & $3.24 \pm 0.04 \mathrm{~b}$ & $3.43 \pm 0.04 \mathrm{~b}$ & $3.46 \pm 0.05 \mathrm{a}$ & $3.56 \pm 0.01 \mathrm{a}$ & $3.74 \pm 0.03 \mathrm{a}$ & $3.51 \pm 0.03 \mathrm{a}$ & $3.59 \pm 0.02 \mathrm{a}$ & $3.6 \pm 0.03 \mathrm{a}$ & $3.52 \pm 0.02 \mathrm{a}$ & $3.54 \pm 0.04 \mathrm{a}$ & 0.000 & 0.248 & 0.003 \\
\hline Ser & $2.9 \pm 0.3$ & $2.92 \pm 0.02$ & $2.91 \pm 0.03$ & $2.91 \pm 0.03$ & $2.73 \pm 0.03$ & $2.85 \pm 0.04$ & $2.89 \pm 0.01$ & $2.95 \pm 0.03$ & $3.18 \pm 0.03$ & $2.85 \pm 0.02$ & $3.08 \pm 0.02$ & $2.98 \pm 0.02$ & $2.96 \pm 0.05$ & $2.95 \pm 0.02$ & 0.176 & 0.462 & 0.25 \\
\hline Glu & $10.85 \pm 0.29 b$ & $10.84 \pm 0.02 b$ & $10.75 \pm 0.35 b$ & $10.85 \pm 0.3 \mathrm{~b}$ & $10.45 \pm 0.03 b$ & $10.68 \pm 0.02 b$ & $10.95 \pm 0.04 \mathrm{~b}$ & $10.83 \pm 0.06 \mathrm{~b}$ & $12.11 \pm 0.03 \mathrm{a}$ & $10.92 \pm 0.02 \mathrm{a}$ & $11.65 \pm 0.05 \mathrm{a}$ & $11.27 \pm 0.03 \mathrm{a}$ & $12.06 \pm 0.03 \mathrm{a}$ & $11.42 \pm 0.02 \mathrm{a}$ & 0.000 & 0.003 & 0.004 \\
\hline Gly & $4.69 \pm 0.26 \mathrm{c}$ & $4.67 \pm 0.06 \mathrm{c}$ & $5.01 \pm 0.19 \mathrm{a}$ & $4.99 \pm 0.32 \mathrm{a}$ & $5.19 \pm 0.04 \mathrm{a}$ & $5.13 \pm 0.03 \mathrm{a}$ & $5.12 \pm 0.02 \mathrm{~b}$ & $4.6 \pm 0.1 \mathrm{~b}$ & $4.56 \pm 0.03 \mathrm{c}$ & $4.05 \pm 0.02 \mathrm{c}$ & $5.33 \pm 0.03 \mathrm{~b}$ & $4.76 \pm 0.02 \mathrm{~b}$ & $5.24 \pm 0.04 \mathrm{a}$ & $5.03 \pm 0.03 \mathrm{a}$ & 0.000 & 0.001 & 0.141 \\
\hline Ala & $6.52 \pm 0.02 \mathrm{c}$ & $6.45 \pm 0.03 \mathrm{c}$ & $7.01 \pm 0.09 \mathrm{bc}$ & $6.48 \pm 0.14 \mathrm{bc}$ & $7.2 \pm 0.2 \mathrm{a}$ & $7.32 \pm 0.04 \mathrm{a}$ & $6.47 \pm 0.03 \mathrm{~b}$ & $7.37 \pm 0.07 \mathrm{~b}$ & $6.61 \pm 0.04 \mathrm{~cd}$ & $6.12 \pm 0.02 \mathrm{~cd}$ & $6.54 \pm 0.02 \mathrm{~cd}$ & $6.3 \pm 0.05 \mathrm{~cd}$ & $6.28 \pm 0.06 \mathrm{~d}$ & $6.13 \pm 0.03 \mathrm{~d}$ & 0.000 & 0.139 & 0.000 \\
\hline Cys & $1.27 \pm 0.06 \mathrm{ab}$ & $1.29 \pm 0.07 \mathrm{ab}$ & $1.27 \pm 0.07 \mathrm{ab}$ & $1.35 \pm 0.05 \mathrm{ab}$ & $1.27 \pm 0.05 \mathrm{a}$ & $1.41 \pm 0.01 \mathrm{a}$ & $1.34 \pm 0.02 \mathrm{a}$ & $1.31 \pm 0.06 \mathrm{a}$ & $1.13 \pm 0.04 \mathrm{ab}$ & $1.36 \pm 0.03 \mathrm{ab}$ & $1.01 \pm 0.01 \mathrm{ab}$ & $1.38 \pm 0.01 \mathrm{ab}$ & $1.22 \pm 0.04 \mathrm{~b}$ & $1.13 \pm 0.03 \mathrm{~b}$ & 0.012 & 0.001 & 0.002 \\
\hline Val & $2.91 \pm 0.03 \mathrm{~b}$ & $3.22 \pm 0.02 \mathrm{~b}$ & $3.12 \pm 0.04 \mathrm{~b}$ & $3 \pm 0.15 \mathrm{~b}$ & $3.02 \pm 0.02 \mathrm{~b}$ & $2.98 \pm 0.04 \mathrm{~b}$ & $3.11 \pm 0.04 \mathrm{~b}$ & $2.99 \pm 0.1 \mathrm{~b}$ & $3.42 \pm 0.03 \mathrm{a}$ & $3.28 \pm 0.01 \mathrm{a}$ & $3.3 \pm 0.1 \mathrm{ab}$ & $3.26 \pm 0.01 \mathrm{ab}$ & $3.27 \pm 0.07 \mathrm{ab}$ & $3.24 \pm 0.04 \mathrm{ab}$ & 0.000 & 0.465 & 0.046 \\
\hline Met & $2.05 \pm 0.05 \mathrm{a}$ & $2.09 \pm 0.09 \mathrm{a}$ & $1.99 \pm 0.07 \mathrm{ab}$ & $1.88 \pm 0.09 \mathrm{ab}$ & $1.83 \pm 0.03 \mathrm{~b}$ & $1.89 \pm 0.06 \mathrm{~b}$ & $2.1 \pm 0.1 \mathrm{a}$ & $2.03 \pm 0.03 \mathrm{a}$ & $2.03 \pm 0.04 \mathrm{ab}$ & $1.84 \pm 0.01 \mathrm{ab}$ & $1.91 \pm 0.03 \mathrm{ab}$ & $1.88 \pm 0.04 \mathrm{ab}$ & $1.86 \pm 0.03 \mathrm{ab}$ & $1.9 \pm 0.05 \mathrm{ab}$ & 0.01 & 0.248 & 0.327 \\
\hline Ile & $3.15 \pm 0.04 b c$ & $3.26 \pm 0.05 b c$ & $3.25 \pm 0.05 \mathrm{bc}$ & $3.19 \pm 0.06 \mathrm{bc}$ & $3.03 \pm 0.01 \mathrm{c}$ & $3.16 \pm 0.02 \mathrm{c}$ & $3.06 \pm 0.02 \mathrm{c}$ & $3.16 \pm 0.03 \mathrm{c}$ & $3.52 \pm 0.04 \mathrm{a}$ & $3.34 \pm 0.02 \mathrm{a}$ & $3.41 \pm 0.03 \mathrm{a}$ & $3.38 \pm 0.03 \mathrm{a}$ & $3.28 \pm 0.06 \mathrm{~b}$ & $3.24 \pm 0.02 \mathrm{~b}$ & 0.000 & 0.829 & 0.007 \\
\hline Leu & $5.31 \pm 0.03 \mathrm{c}$ & $5.51 \pm 0.01 \mathrm{c}$ & $5.43 \pm 0.06 \mathrm{c}$ & $5.46 \pm 0.02 \mathrm{c}$ & $5.11 \pm 0.01 \mathrm{~d}$ & $5.24 \pm 0.04 d$ & $5.33 \pm 0.03 \mathrm{c}$ & $5.45 \pm 0.04 \mathrm{c}$ & $6.06 \pm 0.02 \mathrm{a}$ & $5.68 \pm 0.04 \mathrm{a}$ & $5.81 \pm 0.03 \mathrm{a}$ & $5.74 \pm 0.04 \mathrm{a}$ & $5.61 \pm 0.01 \mathrm{~b}$ & $5.63 \pm 0.03 b$ & 0.000 & 0.676 & 0.000 \\
\hline Tyr & $2.93 \pm 0.04 \mathrm{ab}$ & $3.02 \pm 0.02 \mathrm{ab}$ & $2.92 \pm 0.03 \mathrm{ab}$ & $3.09 \pm 0.01 \mathrm{ab}$ & $2.73 \pm 0.02 \mathrm{c}$ & $2.77 \pm 0.04 \mathrm{c}$ & $2.88 \pm 0.07 \mathrm{~b}$ & $2.98 \pm 0.08 \mathrm{~b}$ & $3.12 \pm 0.01 \mathrm{a}$ & $3.06 \pm 0.01 \mathrm{a}$ & $3.12 \pm 0.04 \mathrm{a}$ & $2.93 \pm 0.03 \mathrm{a}$ & $2.9 \pm 0.02 b$ & $2.88 \pm 0.08 \mathrm{~b}$ & 0.000 & 0.388 & 0.008 \\
\hline Phe & $2.94 \pm 0.08 \mathrm{~b}$ & $3.03 \pm 0.03 b$ & $3.16 \pm 0.03 \mathrm{a}$ & $3.32 \pm 0.03 \mathrm{a}$ & $2.93 \pm 0.02 \mathrm{~b}$ & $3.03 \pm 0.02 \mathrm{~b}$ & $3.09 \pm 0.08 \mathrm{~b}$ & $2.98 \pm 0.04 \mathrm{~b}$ & $3.39 \pm 0.02 \mathrm{a}$ & $3.18 \pm 0.02 \mathrm{a}$ & $3.17 \pm 0.02 \mathrm{a}$ & $3.23 \pm 0.03 \mathrm{a}$ & $3.24 \pm 0.02 \mathrm{a}$ & $3.21 \pm 0.07 \mathrm{a}$ & 0.000 & 0.708 & 0.007 \\
\hline Lys & $5.62 \pm 0.07 \mathrm{a}$ & $5.77 \pm 0.05 \mathrm{a}$ & $5.9 \pm 0.4 \mathrm{a}$ & $5.77 \pm 0.06 \mathrm{a}$ & $5.39 \pm 0.04 \mathrm{a}$ & $5.64 \pm 0.03 \mathrm{a}$ & $5.73 \pm 0.03 \mathrm{a}$ & $5.79 \pm 0.04 \mathrm{a}$ & $5.96 \pm 0.02 \mathrm{a}$ & $5.08 \pm 0.04 \mathrm{a}$ & $5.52 \pm 0.05 \mathrm{a}$ & $5.39 \pm 0.02 \mathrm{a}$ & $5.5 \pm 0.05 \mathrm{~b}$ & $5.29 \pm 0.09 \mathrm{~b}$ & 0.015 & 0.062 & 0.006 \\
\hline
\end{tabular}




\begin{tabular}{|c|c|c|c|c|c|c|c|c|c|c|c|c|c|c|c|c|c|}
\hline His & $1.68 \pm 0.01 \mathrm{a}$ & $1.6 \pm 0.05 \mathrm{a}$ & $1.66 \pm 0.1 \mathrm{a}$ & $1.67 \pm 0.05 \mathrm{a}$ & $1.5 \pm 0.1 \mathrm{a}$ & $1.58 \pm 0.03 \mathrm{a}$ & $1.66 \pm 0.04 \mathrm{a}$ & $1.59 \pm 0.04 \mathrm{a}$ & $1.47 \pm 0.01 \mathrm{a}$ & $1.62 \pm 0.02 \mathrm{a}$ & $1.54 \pm 0.04 \mathrm{a}$ & $1.58 \pm 0.01 \mathrm{a}$ & $1.45 \pm 0.05 \mathrm{~b}$ & $1.46 \pm 0.06 \mathrm{~b}$ & 0.026 & 0.509 & 0.423 \\
\hline Arg & $6.95 \pm 0.1 \mathrm{a}$ & $6.95 \pm 0.03 a$ & $7.4 \pm 0.3 \mathrm{a}$ & $6.95 \pm 0.05 \mathrm{a}$ & $6.84 \pm 0.04 \mathrm{a}$ & $7.05 \pm 0.02 \mathrm{a}$ & $6.83 \pm 0.03 \mathrm{a}$ & $6.98 \pm 0.03 \mathrm{a}$ & $7.15 \pm 0.02 \mathrm{~b}$ & $5.29 \pm 0.02 \mathrm{~b}$ & $7.25 \pm 0.02 \mathrm{a}$ & $6.85 \pm 0.03 a$ & $7.13 \pm 0.01 \mathrm{a}$ & $6.81 \pm 0.01 \mathrm{a}$ & 0.000 & 0.000 & 0.000 \\
\hline Pro & $3.97 \mathrm{a}$ & $3.86 \pm 0.06 \mathrm{a}$ & $3.9 \pm 0.3 \mathrm{ab}$ & $3.65 \pm 0.05 \mathrm{ab}$ & $3.78 \pm 0.04 \mathrm{ab}$ & $3.94 \pm 0.02 \mathrm{ab}$ & $4.14 \pm 0.04 \mathrm{a}$ & $4.03 \pm 0.02 \mathrm{a}$ & $2.66 \pm 0.01 \mathrm{c}$ & $2.93 \pm 0.03 \mathrm{c}$ & $3.32 \pm 0.02 \mathrm{~b}$ & $3.85 \pm 0.05 \mathrm{~b}$ & $2.82 \pm 0.04 \mathrm{c}$ & $2.97 \pm 0.02 \mathrm{c}$ & 0.000 & 0.082 & 0.011 \\
\hline TAA & $74.19 \pm 1.65$ & $75.36 \pm 0.85$ & $76.48 \pm 2.16$ & $75.38 \pm 1.55$ & $72.93 \pm 0.8$ & $75.15 \pm 0.55$ & $75.26 \pm 0.85$ & $75.82 \pm 0.84$ & $77.55 \pm 0.45$ & $71.27 \pm 0.56$ & $76.85 \pm 0.56$ & $75.61 \pm 0.47$ & $75.49 \pm 0.63$ & $73.89 \pm 0.66$ & 0.329 & 0.124 & 0.023 \\
\hline EAA & $25.44 \pm 0.33 b$ & $26.45 \pm 0.29 \mathrm{~b}$ & $26.38 \pm 0.68 \mathrm{a}$ & $26.14 \pm 0.45 \mathrm{a}$ & $24.55 \pm 0.17 \mathrm{~b}$ & $25.38 \pm 0.25 b$ & $25.87 \pm 0.35 \mathrm{~b}$ & $25.95 \pm 0.32 \mathrm{~b}$ & $28.12 \pm 0.17 \mathrm{a}$ & $25.89 \pm 0.17 \mathrm{a}$ & $26.7 \pm 0.28 \mathrm{a}$ & $26.47 \pm 0.2 \mathrm{a}$ & $26.28 \pm 0.26 \mathrm{a}$ & $26.04 \pm 0.34 \mathrm{a}$ & 0.001 & 0.424 & 0.006 \\
\hline NEAA & $48.75 \pm 1.32$ & $48.91 \pm 0.56$ & $50.1 \pm 1.48$ & $49.24 \pm 1.1$ & $48.38 \pm 0.63$ & $49.77 \pm 0.3$ & $49.39 \pm 0.5$ & $49.87 \pm 0.52$ & $49.44 \pm 0.28$ & $45.38 \pm 0.39$ & $50.15 \pm 0.29$ & $49.14 \pm 0.27$ & $49.22 \pm 0.37$ & $47.85 \pm 0.32$ & 0.062 & 0.068 & 0.043 \\
\hline DAA & $29.06 \pm 0.74$ & $29.26 \pm 0.31$ & $30.04 \pm 0.65$ & $29.62 \pm 0.86$ & $29.53 \pm 0.35$ & $30.17 \pm 0.13$ & $29.65 \pm 0.29$ & $30.03 \pm 0.28$ & $30.72 \pm 0.15$ & $28.28 \pm 0.26$ & $30.83 \pm 0.13$ & $29.58 \pm 0.12$ & $30.74 \pm 0.16$ & $29.64 \pm 0.1$ & 0.196 & 0.019 & 0.02 \\
\hline AA/TAA & 0.34 & 0.35 & 0.34 & 0.35 & 0.34 & 0.34 & 0.34 & 0.34 & 0.36 & 0.36 & 0.35 & 0.35 & 0.35 & 0.35 & - & - & - \\
\hline
\end{tabular}

3 Different letters represent significant differences among sites for $p<0.05$.

4 Asp, Aspartic acid; Thr, Threonine; Ser, Serine; Glu, Glutamic acid; Gly, Glycine; Ala, Alanine; Cys, Cystine; Val, Valine; Met, Methionine; Ile,

5 Isoleucine; Leu, Leucine; Tyr, Tyrosine; Phe, Phenylalanine; Lys, Lysine; His, Histidine; Arg, Arginine; Pro, Proline. TAA, total amino acids; EAA,

6 essential amino acids; NEAA, non-essential amino acids; DAA, delicious amino acids; EAA/TAA, essential amino acids/total amino acids. 


\section{Table 5 (on next page)}

Main and interactive effects of sampling sites and sex on muscle amino acid concentration of mitten crab.

Asp, Aspartic acid; Thr, Threonine; Ser, Serine; Glu, Glutamic acid; Gly, Glycine; Ala, Alanine; Cys, Cystine; Val, Valine; Met, Methionine; Ile, Isoleucine; Leu, Leucine; Tyr, Tyrosine; Phe, Phenylalanine; Lys, Lysine; His, Histidine; Arg, Arginine; Pro, Proline. TAA, total amino acids; EAA, essential amino acids; NEAA, non-essential amino acids; DAA, delicious amino acids; EAA/TAA, essential amino acids/total amino acids. 
Table 5 Main and interactive effects of sampling sites and sex on muscle amino acid concentration of mitten crab.

\begin{tabular}{|c|c|c|c|c|c|c|c|}
\hline \multirow{2}{*}{ Measurement } & \multicolumn{2}{|c|}{ Sampling sites } & \multicolumn{2}{|c|}{ sex } & \multicolumn{2}{|c|}{ Interaction } & \multirow{2}{*}{$R^{2}$} \\
\hline & $F(6,13)$ & $p$ & $F(1,13)$ & $p$ & $F(6,13)$ & $p$ & \\
\hline Asp & 3.91 & 0.017 & 0.87 & 0.366 & 1.95 & 0.142 & 0.720 \\
\hline Thr & 11.98 & 0.000 & 1.452 & 0.248 & 6.07 & 0.003 & 0.887 \\
\hline Ser & 1.78 & 0.176 & 0.57 & 0.462 & 1.50 & 0.250 & 0.591 \\
\hline Glu & 18.02 & 0.000 & 13.05 & 0.003 & 5.54 & 0.004 & 0.917 \\
\hline Gly & 11.36 & 0.000 & 15.97 & 0.001 & 1.96 & 0.141 & 0.873 \\
\hline Ala & 44.07 & 0.000 & 2.47 & 0.139 & 19.04 & 0.000 & 0.965 \\
\hline Cys & 4.29 & 0.012 & 19.20 & 0.001 & 6.53 & 0.002 & 0.857 \\
\hline Val & 9.43 & 0.000 & 0.56 & 0.465 & 2.93 & 0.046 & 0.842 \\
\hline Met & 4.42 & 0.010 & 1.45 & 0.248 & 1.28 & 0.327 & 0.718 \\
\hline Ile & 25.06 & 0.000 & 0.05 & 0.829 & 4.85 & 0.007 & 0.928 \\
\hline Leu & 119.52 & 0.000 & 0.18 & 0.676 & 18.87 & 0.000 & 0.983 \\
\hline Tyr & 15.96 & 0.000 & 0.79 & 0.388 & 4.73 & 0.008 & 0.899 \\
\hline Phe & 19.42 & 0.000 & 0.15 & 0.708 & 4.93 & 0.007 & 0.913 \\
\hline Lys & 4.03 & 0.015 & 4.11 & 0.062 & 5.01 & 0.006 & 0.807 \\
\hline His & 3.46 & 0.026 & 0.46 & 0.509 & 1.07 & 0.423 & 0.664 \\
\hline Arg & 26.34 & 0.000 & 70.72 & 0.000 & 34.41 & 0.000 & 0.969 \\
\hline Pro & 62.73 & 0.000 & 3.52 & 0.082 & 4.31 & 0.011 & 0.967 \\
\hline TAA & 1.28 & 0.329 & 2.68 & 0.124 & 3.57 & 0.023 & 0.694 \\
\hline EAA & 7.49 & 0.001 & 0.68 & 0.424 & 4.99 & 0.006 & 0.844 \\
\hline NEAA & 2.65 & 0.062 & 3.92 & 0.068 & 2.99 & 0.043 & 0.730 \\
\hline DAA & 1.69 & 0.196 & 7.03 & 0.019 & 3.74 & 0.020 & 0.739 \\
\hline EAA/TAA & 89.87 & 0.000 & 14.99 & 0.002 & 3.27 & 0.032 & 0.976 \\
\hline
\end{tabular}

Asp, Aspartic acid; Thr, Threonine; Ser, Serine; Glu, Glutamic acid; Gly, Glycine; Ala, Alanine;

Cys, Cystine; Val, Valine; Met, Methionine; Ile, Isoleucine; Leu, Leucine; Tyr, Tyrosine; Phe,

Phenylalanine; Lys, Lysine; His, Histidine; Arg, Arginine; Pro, Proline. TAA, total amino acids;

EAA, essential amino acids; NEAA, non-essential amino acids; DAA, delicious amino acids;

EAA/TAA, essential amino acids/total amino acids. 


\section{Table 6(on next page)}

Main and interactive effects of sampling sites and sex on hepatopancreas amino acid concentration of mitten crab.

Asp, Aspartic acid; Thr, Threonine; Ser, Serine; Glu, Glutamic acid; Gly, Glycine; Ala, Alanine; Cys, Cystine; Val, Valine; Met, Methionine; Ile, Isoleucine; Leu, Leucine; Tyr, Tyrosine; Phe, Phenylalanine; Lys, Lysine; His, Histidine; Arg, Arginine; Pro, Proline. TAA, total amino acids; EAA, essential amino acids; NEAA, non-essential amino acids; DAA, delicious amino acids; EAA/TAA, essential amino acids/total amino acids. 
Table 6 Main and interactive effects of sampling sites and sex on hepatopancreas amino acid concentration of mitten crab.

\begin{tabular}{|c|c|c|c|c|c|c|c|}
\hline \multirow{2}{*}{ Measurement } & \multicolumn{2}{|c|}{ Sampling sites } & \multicolumn{2}{|c|}{ sex } & \multicolumn{2}{|c|}{ Interaction } & \multirow{2}{*}{$R^{2}$} \\
\hline & $F(6,13)$ & $p$ & $F(1,13)$ & $p$ & $F(6,13)$ & $p$ & \\
\hline Asp & 8.34 & 0.001 & 12.06 & 0.004 & 7.28 & 0.001 & 0.883 \\
\hline Thr & 9.86 & 0.000 & 14.07 & 0.002 & 4.90 & 0.007 & 0.880 \\
\hline Ser & 3.01 & 0.042 & 4.93 & 0.043 & 1.84 & 0.163 & 0.708 \\
\hline Glu & 30.77 & 0.000 & 38.56 & 0.000 & 15.23 & 0.000 & 0.957 \\
\hline Gly & 7.12 & 0.001 & 14.13 & 0.002 & 4.78 & 0.007 & 0.859 \\
\hline Ala & 18.18 & 0.000 & 36.64 & 0.000 & 11.53 & 0.000 & 0.939 \\
\hline Cys & 4.59 & 0.009 & 6.57 & 0.023 & 3.20 & 0.034 & 0.792 \\
\hline Val & 7.87 & 0.001 & 8.14 & 0.013 & 6.17 & 0.002 & 0.868 \\
\hline Met & 1.70 & 0.194 & 1.14 & 0.303 & 1.66 & 0.203 & 0.603 \\
\hline Ile & 4.60 & 0.009 & 8.56 & 0.011 & 3.41 & 0.027 & 0.802 \\
\hline Leu & 10.60 & 0.000 & 15.54 & 0.001 & 6.61 & 0.002 & 0.895 \\
\hline Tyr & 11.02 & 0.000 & 25.21 & 0.000 & 8.80 & 0.000 & 0.911 \\
\hline Phe & 6.09 & 0.003 & 6.85 & 0.02 & 5.33 & 0.005 & 0.843 \\
\hline Lys & 14.23 & 0.000 & 14.12 & 0.002 & 8.38 & 0.001 & 0.915 \\
\hline His & 2.57 & 0.068 & 0.27 & 0.614 & 1.36 & 0.297 & 0.630 \\
\hline Arg & 24.12 & 0.000 & 35.93 & 0.000 & 21.29 & 0.000 & 0.957 \\
\hline Pro & 26.41 & 0.000 & 50.99 & 0.000 & 4.34 & 0.011 & 0.944 \\
\hline TAA & 11.67 & 0.000 & 18.98 & 0.001 & 7.51 & 0.001 & 0.905 \\
\hline EAA & 10.44 & 0.000 & 13.35 & 0.003 & 7.13 & 0.001 & 0.895 \\
\hline NEAA & 12.10 & 0.000 & 22.01 & 0.000 & 7.50 & 0.001 & 0.909 \\
\hline DAA & 17.33 & 0.000 & 28.52 & 0.000 & 10.74 & 0.000 & 0.934 \\
\hline EAA/TAA & 4.51 & 0.009 & 12.17 & 0.004 & 1.54 & 0.236 & 0.776 \\
\hline
\end{tabular}

Asp, Aspartic acid; Thr, Threonine; Ser, Serine; Glu, Glutamic acid; Gly, Glycine; Ala, Alanine;

Cys, Cystine; Val, Valine; Met, Methionine; Ile, Isoleucine; Leu, Leucine; Tyr, Tyrosine; Phe,

Phenylalanine; Lys, Lysine; His, Histidine; Arg, Arginine; Pro, Proline. TAA, total amino acids;

EAA, essential amino acids; NEAA, non-essential amino acids; DAA, delicious amino acids;

EAA/TAA, essential amino acids/total amino acids. 


\section{Table 7 (on next page)}

Main and interactive effects of sampling sites and sex on gonad amino acid concentration of mitten crab.

Asp, Aspartic acid; Thr, Threonine; Ser, Serine; Glu, Glutamic acid; Gly, Glycine; Ala, Alanine; Cys, Cystine; Val, Valine; Met, Methionine; Ile, Isoleucine; Leu, Leucine; Tyr, Tyrosine; Phe, Phenylalanine; Lys, Lysine; His, Histidine; Arg, Arginine; Pro, Proline. TAA, total amino acids; EAA, essential amino acids; NEAA, non-essential amino acids; DAA, delicious amino acids; EAA/TAA, essential amino acids/total amino acids. 
Table 7 Main and interactive effects of sampling sites and sex on gonad amino acid concentration of mitten crab.

\begin{tabular}{|c|c|c|c|c|c|c|c|}
\hline \multirow{2}{*}{ Measurement } & \multicolumn{2}{|c|}{ Sampling sites } & \multicolumn{2}{|c|}{ sex } & \multicolumn{2}{|c|}{ Interaction } & \multirow{2}{*}{$R^{2}$} \\
\hline & $F(6,13)$ & $p$ & $F(1,13)$ & $p$ & $F(6,13)$ & $p$ & \\
\hline Asp & 5.32 & 0.005 & 24.62 & 0.000 & 3.22 & 0.033 & 0.994 \\
\hline Thr & 0.20 & 0.971 & 143.82 & 0.000 & 0.313 & 0.92 & 0.913 \\
\hline Ser & 0.05 & 0.999 & 1.91 & 0.188 & 0.26 & 0.945 & 0.213 \\
\hline Glu & 17.76 & 0.000 & 641.72 & 0.000 & 1.88 & 0.154 & 0.982 \\
\hline Gly & 3.25 & 0.032 & 1.27 & 0.279 & 1.93 & 0.146 & 0.698 \\
\hline Ala & 17.95 & 0.000 & 21.96 & 0.000 & 29.62 & 0.000 & 0.994 \\
\hline Cys & 1.87 & 0.157 & 342.13 & 0.000 & 3.20 & 0.034 & 0.964 \\
\hline Val & 2.17 & 0.109 & 823.15 & 0.000 & 1.16 & 0.382 & 0.984 \\
\hline Met & 3.92 & 0.016 & 14.86 & 0.000 & 1.05 & 0.436 & 0.990 \\
\hline Ile & 1.06 & 0.429 & 28.23 & 0.000 & 3.00 & 0.042 & 0.79 \\
\hline Leu & 1.51 & 0.246 & 18.66 & 0.001 & 3.36 & 0.029 & 0.774 \\
\hline Tyr & 4.08 & 0.014 & 125.27 & 0.000 & 5.54 & 0.004 & 0.929 \\
\hline Phe & 2.76 & 0.055 & 120.95 & 0.000 & 1.68 & 0.200 & 0.913 \\
\hline Lys & 10.43 & 0.000 & 425.16 & 0.000 & 3.13 & 0.037 & 0.973 \\
\hline His & 0.15 & 0.986 & 6.34 & 0.025 & 0.08 & 0.997 & 0.356 \\
\hline Arg & 7.23 & 0.001 & 12.38 & 0.000 & 2.40 & 0.083 & 0.99 \\
\hline Pro & 69.08 & 0.000 & 38.29 & 0.000 & 65.4 & 0.000 & 0.99 \\
\hline TAA & 0.151 & 0.986 & 219.29 & 0.000 & 3.56 & 0.024 & 0.945 \\
\hline EAA & 0.248 & 0.952 & 17.23 & 0.001 & 1.86 & 0.159 & 0.681 \\
\hline NEAA & 0.167 & 0.982 & 766.70 & 0.000 & 4.18 & 0.013 & 0.983 \\
\hline DAA & 3.29 & 0.031 & 11.35 & 0.000 & 3.77 & 0.019 & 0.988 \\
\hline EAA/TAA & 0.516 & 0.787 & 10.06 & 0.000 & 0.25 & 0.952 & 0.987 \\
\hline
\end{tabular}

Asp, Aspartic acid; Thr, Threonine; Ser, Serine; Glu, Glutamic acid; Gly, Glycine; Ala, Alanine;

Cys, Cystine; Val, Valine; Met, Methionine; Ile, Isoleucine; Leu, Leucine; Tyr, Tyrosine; Phe,

Phenylalanine; Lys, Lysine; His, Histidine; Arg, Arginine; Pro, Proline. TAA, total amino acids;

EAA, essential amino acids; NEAA, non-essential amino acids; DAA, delicious amino acids;

EAA/TAA, essential amino acids/total amino acids. 


\section{Table 8 (on next page)}

Comparison of AAS, CS, and EAAI in three tissues of mitten crab.

Thr, Threonine; Cys, Cystine; Val, Valine; Met, Methionine; Ile, Isoleucine; Leu, Leucine; Tyr, Tyrosine; Phe, Phenylalanine; Lys, Lysine; EAAl, essential amino acid index; AAS, amino acid score; CS, chemical score. 


\section{Table 4}

2 Comparison of AAS, CS, and EAAI in three tissues of mitten crab.

\begin{tabular}{|c|c|c|c|c|c|c|c|c|c|c|c|c|c|}
\hline SQ & & GN & & SH & & XH & & $\mathrm{GC}$ & & $\mathrm{JT}$ & & SZ & \\
\hline AAS & $\mathrm{CS}$ & AAS & $\mathrm{CS}$ & AAS & $\mathrm{CS}$ & AAS & $\mathrm{CS}$ & AAS & $\mathrm{CS}$ & AAS & CS & AAS & CS \\
\hline
\end{tabular}

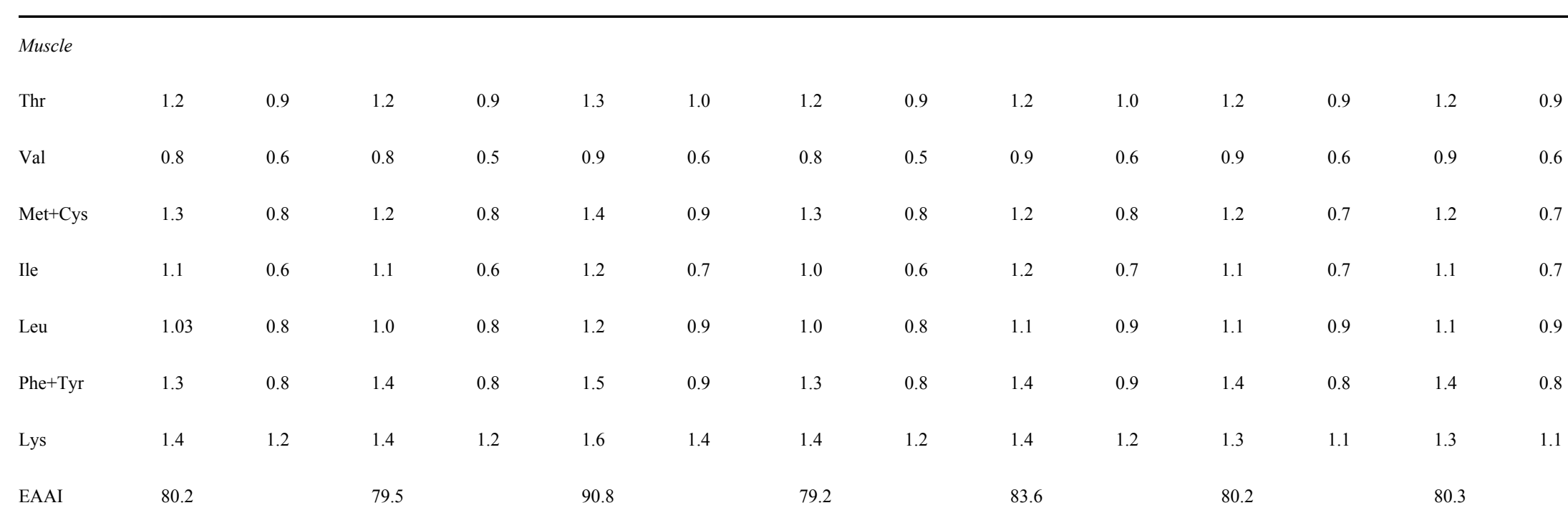

Hepatopancreas

\begin{tabular}{|c|c|c|c|c|c|c|c|c|c|c|c|c|c|}
\hline Thr & 1.4 & 1.1 & 1.5 & 1.1 & 1.4 & 1.1 & 1.5 & 1.2 & 1.5 & 1.2 & 1.5 & 1.2 & 1.4 \\
\hline Val & 1.1 & 0.7 & 1.1 & 0.7 & 1.1 & 0.7 & 1.1 & 0.8 & 1.1 & 0.8 & 1.1 & 0.8 & 1.1 \\
\hline Met+Cys & 1.3 & 0.8 & 1.2 & 0.8 & 1.4 & 0.9 & 1.3 & 0.8 & 1.4 & 0.9 & 1.3 & 0.8 & 1.4 \\
\hline Ile & 1.2 & 0.7 & 1.1 & 0.7 & 1.1 & 0.6 & 1.1 & 0.7 & 1.1 & 0.7 & 1.1 & 0.7 & 1.1 \\
\hline Leu & 1.1 & 0.9 & 1.1 & 0.9 & 1.1 & 0.8 & 1.1 & 0.9 & 1.1 & 0.9 & 1.1 & 0.9 & 1.1 \\
\hline
\end{tabular}




\begin{tabular}{|c|c|c|c|c|c|c|c|c|c|c|c|c|c|c|}
\hline Phe+Tyr & 1.6 & 0.9 & 1.4 & 0.9 & 1.4 & 0.9 & 1.4 & 0.8 & 1.4 & 0.9 & 1.4 & 0.8 & 1.5 & 0.9 \\
\hline Lys & 1.3 & 1.1 & 1.3 & 1.1 & 1.2 & 1.1 & 1.1 & 1.0 & 1.2 & 1.1 & 1.2 & 1.0 & 1.2 & 1.1 \\
\hline EAAI & 88.4 & & 86.3 & & 86.4 & & 87.1 & & 89.9 & & 87.3 & & 87.8 & \\
\hline \multicolumn{15}{|l|}{ Gonad } \\
\hline Thr & 1.8 & 1.4 & 1.8 & 1.4 & 1.9 & 1.5 & 1.9 & 1.5 & 1.9 & 1.5 & 1.9 & 1.5 & 1.9 & 1.5 \\
\hline Val & 0.9 & 0.6 & 1.0 & 0.7 & 1.0 & 0.7 & 1.0 & 0.7 & 1.0 & 0.7 & 1.0 & 0.7 & 1.0 & 0.7 \\
\hline Met+Cys & 1.2 & 0.8 & 1.3 & 0.8 & 1.2 & 0.8 & 1.2 & 0.8 & 1.2 & 0.7 & 1.2 & 0.8 & 1.2 & 0.8 \\
\hline Ile & 1.2 & 0.7 & 1.2 & 0.7 & 1.2 & 0.7 & 1.2 & 0.7 & 1.2 & 0.7 & 1.2 & 0.7 & 1.2 & 0.7 \\
\hline Leu & 1.0 & 0.8 & 1.1 & 0.8 & 1.1 & 0.9 & 1.1 & 0.9 & 1.1 & 0.8 & 1.1 & 0.9 & 1.1 & 0.9 \\
\hline Phe+Tyr & 1.4 & 0.8 & 1.4 & 0.8 & 1.3 & 0.8 & 1.3 & 0.8 & 1.3 & 0.8 & 1.3 & 0.8 & 1.3 & 0.8 \\
\hline Lys & 1.1 & 0.9 & 1.0 & 0.9 & 1.0 & 0.8 & 1.0 & 0.8 & 1.0 & 0.9 & 1.0 & 0.9 & 1.0 & 0.9 \\
\hline EAAI & 83.6 & & 85.8 & & 84.1 & & 84.1 & & 84.0 & & 85.1 & & 83.8 & \\
\hline
\end{tabular}

3 Thr, Threonine; Cys, Cystine; Val, Valine; Met, Methionine; Ile, Isoleucine; Leu, Leucine; Tyr, Tyrosine; Phe, Phenylalanine; Lys, Lysine; EAAI,

essential amino acid index. 